\title{
Intrusion related gold deposits in the Tanami and Kurundi-Kurinelli goldfields, Northern Territory, Australia: Constraints from LA-ICPMS analysis of fluid inclusions
}

\author{
Li Zhou ${ }^{\mathrm{a}, \mathrm{b}}$, Terrence P. Mernagh ${ }^{\mathrm{b}, \mathrm{c}, *}$, TingGuang Lan ${ }^{\mathrm{d}}$, Yanwen Tang ${ }^{\mathrm{d}}$, Andrew Wygralak ${ }^{\mathrm{e}}$ \\ ${ }^{a}$ School of Geography and Environmental Science, Guizhou Normal University, Guiyang 550001, China \\ ${ }^{\mathrm{b}}$ Key Laboratory of High-temperature and High-pressure Study of the Earth's Interior, Institute of Geochemistry, Chinese Academy of Sciences, Guiyang 550002, China \\ ${ }^{\mathrm{c}}$ Research School of Earth Sciences, The Australian National University, Acton, ACT 2601, Australia \\ ${ }^{\mathrm{d}}$ State Key Laboratory of Ore Deposit Geochemistry, Institute of Geochemistry, Chinese Academy of Sciences, Guiyang 550002, China \\ ${ }^{\mathrm{e}}$ Northern Territory Geological Survey, GPO Box 4550, Darwin, NT 0801, Australia
}

\section{A R T I C L E I N F O}

\section{Keywords:}

Intrusion related gold deposits

Fluid inclusions

LA-ICPMS

Cathodoluminescence

Northern Australia

\begin{abstract}
A B S T R A C T
Gold deposits in the Tanami and Kurundi-Kurinelli goldfields of the Northern Territory, Australia, have geological and geochemical characteristics that distinguish them from the typical vein-hosted, orogenic gold deposits that occur in other parts of Australia. This study used cathodoluminescence (CL) and laser ablation inductively coupled plasma mass spectrometry (LA-ICPMS) analyses of fluid inclusions to investigate the source of mineralising fluids from both the highly mineralised Tanami goldfield and weakly mineralised Kurundi-Kurinelli goldfields in northern Australia. Cathodoluminescence showed three generations of quartz in fractured and mineralised veins from the Groundrush deposit in the Tanami goldfield but the remaining deposits had uniform dark CL images.

The LA-ICPMS trace element data indicate an evolution from B-As-enriched, magmatic fluid to a highly Sr-Baenriched fluid which results from interaction with sedimentary rocks. The fluids from both regions have chlorinity normalised $\mathrm{Zn}$ and $\mathrm{Pb}$ concentrations at the magmatic end of the metamorphic - magmatic mixing trend for these elements. This is in agreement with previous studies showing that gold mineralisation is coeval with magmatism in the Tanami region. The relatively high salinity of the fluids in both the Tanami and Kurundi - Kurinelli goldfields, and their trace element contents indicates that the deposits in both regions are intrusionrelated gold deposits. The higher gold endowment of the Tanami region may result from the multiple goldmineralisation events in this region whereas fluid flow associated with mineralisation in the Kurundi - Kurinelli goldfields appears to be of limited extent.
\end{abstract}

\section{Introduction}

The distinction between intrusion-related gold deposits (IRGD) and orogenic gold deposits (OGD) remains a subject of debate (e.g. Groves et al., 2003; Hart and Goldfarb, 2005). Australia has a range of gold deposits that may be classified as either orogenic-gold or intrusion-related gold deposits (Mernagh et al., 2007). OGDs typically form along convergent margins during the late part of the deformational-metamorphic history of terrane accretion (Groves et al., 2003). These deposits have a strong structural control involving faults or shear zones, folds, and/or zones of competency contrast. Host rocks are extremely variable, although there is an overall trend from volcanic-or intrusionhosted deposits in Archean provinces to sedimentary rock-hosted deposits in Phanerozoic provinces. Although the host rocks vary from subgeenschist to granulite facies, the majority of OGDs are hosted in greenschist facies rocks. Quartz \pm carbonate veins are ubiquitous and the deposits may extend to depths of up to $1 \mathrm{~km}$ or more, with only subtle metal zoning, and strong, lateral zonation of wall-rock alteration. A distinctive metal association (Au-Ag $\pm \mathrm{As} \pm \mathrm{B} \pm \mathrm{Bi} \pm \mathrm{Sb} \pm$ $\mathrm{Te} \pm \mathrm{W}$ ) is also characteristic of OGDs (McCuaig and Kerrich, 1998; Ridley and Diamond, 2000; Goldfarb et al., 2005).

IRGDs may be classified into two broad groups. The first group occur in copper poor or absent portions of typical porphyry copper systems, associated with oxidised magmatic complexes. The second group occur in base metal poor or absent portions of intermediate to reduced magmatic complexes and are typically associated with Au-Bitelluride or Au-As-Mo-Sb systems. This second type bears many similarities to OGDs and is what is referred to as an IRGD in this paper.

\footnotetext{
* Corresponding author at: Research School of Earth Sciences, The Australian National University, Acton, ACT 2601, Australia.

E-mail address: Terry.Mernagh@anu.edu.au (T.P. Mernagh).
} 
IRGDs typically occur in a continental tectonic setting well inboard of inferred or recognized convergent plate boundaries, in a landward or backarc position, or within continental collisional settings (Thompson and Newberry, 2000). Intrusion-related mineralisation tends to be younger than the penetrative fabric of the host rocks, whereas, orogenic mineralisation is synchronous with, or postdates penetrative fabrics and structures. IRGDs also contain a metal suite that is very similar to OGDs which sometimes also includes distal Pb-Zn. However, Blevin (2005) has stated that the base metal contents of IRGDs are highly variable and may be almost absent. The Au-rich portion of granitoid related mineral deposits may be locally distant from the higher temperature parts of the hydrothermal system, and obvious genetic links between the Au-rich portions of IRGD deposits and their related granitoids may be difficult to establish (Blevin, 2004).

IRGD deposits are related genetically to felsic igneous rocks (granite/rhyolite) of intermediate oxidation state (magnetite contents may be low or absent). The deposits exhibit a range of characteristics that vary over a wide range of emplacement depths $(<1 \mathrm{~km}$ to $>7$ $\mathrm{km})$. Deposits in shallow crustal settings ( $\leq 5 \mathrm{~km}$ ) are associated with stocks, sills, dykes and volcanic domes and include systems with epithermal-style veins to breccia and stockwork similar to porphyry-type settings. Deeper systems ( $\geq 5 \mathrm{~km}$ ) have characteristics of mesothermal environments, and are hosted by plutons containing sheeted veins, greisen and disseminated gold.

Many researchers favour a metamorphic fluid source for OGDs (e.g. Phillips, 1993; Goldfarb et al., 2005; Ridley and Diamond, 2000; Goldfarb and Groves, 2015; Phillips and Powell, 2010; Beaudoin and Chiaradia, 2016; Fusswinkel et al., 2017). These deposits are typically associated with aqueous-carbonic fluids with low to intermediate salinity (3-13 wt $\% \mathrm{NaCl}$ equiv.), $\mathrm{XCO}_{2} \approx 0.1-0.15, \delta^{18} \mathrm{O}=6-13 \%$, and $\mathrm{P}$ $\mathrm{T}$ conditions of $\sim 250-350{ }^{\circ} \mathrm{C}$ and $1-3 \mathrm{kbar}$, respectively (McCuaig and Kerrich, 1998; Ridley and Diamond, 2000; Goldfarb et al., 2005). However, it is well known that IRGDs can also produce mineralising fluids having both variable salinities and $\mathrm{CO}_{2}$ contents (e.g., Thompson and Newberry, 2000; Baker and Lang, 2001; Lang and Baker, 2001; Baker, 2002; Marsh et al., 2003; Hart, 2007).

Fortunately, the differences between magmatic and metamorphic fluids can be determined by laser ablation inductively coupled plasma mass spectrometry (LA-ICPMS) analysis. There have been several LAICPMS studies of magmatic fluid inclusions (e.g., Audétat et al., 1998, 2008; Ulrich et al., 1999, 2002; Rusk et al., 2004; Seo et al., 2012; Harlaux et al., 2017). At present most of the data for magmatic fluids are from porphyry-epithermal systems and a few are from Li-enriched, evolved granite intrusions. Detailed studies of fluid inclusions associated with metamorphic fluids are now also being reported (e.g. Klemm et al., 2004; Marsala et al., 2013; Rauchenstein-Martinek et al., 2014; Fusswinkel et al., 2017).

Fusswinkel et al. (2017) reported LA-ICPMS data from fluid inclusions from the Pampalo OGD, located in the Neoarchean Hattu schist belt in Eastern Finland and demonstrated that it was possible to obtain reliable LA-ICPMS from orogenic gold style fluid inclusions ranging from 5 to $15 \mu \mathrm{m}$ diameter. They used mass balance calculations as well as $\mathrm{Cl} / \mathrm{Br}$ ratios to demonstrate that the composition of the early Au-rich fluid at Pampalo is not compatible with any significant magmatic-hydrothermal fluid contribution. However, Kerr et al. (2018) carried out LA-ICPMS analyses of fluid inclusions from the Madrid OGD in Canada and found that the deposit had been upgraded by the influx of fluids enriched in As-Sb-Cs-Ba-Rb-Sr-Zn-Pb, which is consistent with fluids derived from an evolved magmatic-hydrothermal system.

Many of the LA-ICPMS studies of fluid inclusions from IRGDs have focused on the deposits in the Tintina Gold Province of Alaska and Yukon, which is the type locality for these deposits (Hart and Goldfarb, 2005). Marsh et al. (2003, 2005) reported LA-ICPMS data for fluid inclusions from a number of deposits in this region that have $\mathrm{CO}_{2}$-rich and low to moderate salinity fluids. Ridley (2006) also conducted microthermometry and LA-ICPMS analysis of fluid inclusions from this province and reported that the dominance of low- to moderate-salinity, aqueous-carbonic fluids and the uniformity of their compositions in hydrothermal systems of post-metamorphic, syn-intrusion age, irrespective of setting and distance from coeval intrusions, are consistent with IRGD fluids. Thus low- to moderate-salinity fluids may exist in both OGDs and IRGDs and other parameters are needed to distinguish between these deposits. On the other hand, moderate to high temperature, high salinity fluids are closely associated with intrusion-related systems.

Mernagh and Wygralak (2007) and Wygralak and Mernagh (2008) have studied a large number of gold deposits in the Tanami Region and the Warramunga Province. The results of these studies indicated that the mineralising fluids were either of magmatic or metamorphic origin, thus making it difficult to determine if they were OGDs or IRGDs. In this study we have used LA-ICPMS data from fluid inclusions from these Proterozoic goldfields in northern Australia to accurately identify the source of fluids associated with mineralisation. We also compared the fluid chemistry of the deposits to investigate if it may be responsible for the different gold endowments of the two Proterozoic goldfields.

\section{Geological setting}

\subsection{Tanami region}

The Tanami Region represents an area of lower greenschist- to amphibolite-facies Palaeoproterozoic metasedimentary and volcanic rocks overlying Archaean basement and intruded by 1825-1791 Ma granites. These straddle the Northern Territory - Western Australia border and are unconformably overlain by the Birrindudu Basin to the north, Wiso Basin to the east and Canning Basin to the west (Fig. 1). The Tanami Region has been divided into two main groups (Ahmad et al., 2013): Ware Group and Tanami Group (Fig. 2). Voluminous granitoids, dominated by metaluminous, I type biotite granodiorite and monzogranite, outcrop over more than half of the Tanami Region. These granites intruded at 1825-1790 Ma and have been subdivided on geochemical criteria into the Birthday, Frederick and Grimwade suites (Fig. 2). With known resources of more than 250 tonnes of gold, the Tanami Region (Fig. 2) is the largest Palaeoproterozoic gold province in Australia and one of the preeminent Proterozoic gold provinces in the world (Ahmad et al., 2013; Huston et al., 2007). This region hosts over 121 known gold occurrences in both the Northern Territory and Western Australia. Mineralisation in the Tanami Region has been grouped into a number of separate gold camps (Fig. 2). The main camp is the Dead Bullock Soak (DBS) goldfield. Callie is the largest deposit in this goldfield with a resource of $7.6 \mathrm{Moz}$ gold (Baggott et al., 2016). Other mines in this goldfield include Gahn, Villa, Triumph-Colliwobble and DBR. At the Callie mine, sheeted, planar to weakly boudinaged quartz veins up to $20 \mathrm{~cm}$ thick host free gold with variable carbonate, chlorite, biotite, feldspar, and sulfide minerals. These veins dip $20^{\circ}$ to $63^{\circ}$ and define a series of E-W-trending corridors. Ore veins are generally surrounded by a narrow zone of wall rock alteration that varies with depth, with chlorite being progressively replaced by biotite as the dominant phyllosilicate (Huston et al., 2007).

The Granites goldfield, located $40 \mathrm{~km}$ to the east of the DBS goldfield, contains four significant deposits: Bullakitchie, Bunkers Hill, Shoe and Quorn. In the Granites goldfield, besides the quartz-only veins, gold also occurs in chlorite bands within quartz-chlorite veins and as grains associated with sulfide and arsenide minerals disseminated in bandediron formation (BIF). The highest gold grades are associated with sulfide-rich amphibole schist and with carbonate-rich facies BIF (Huston et al., 2007).

The Tanami goldfield is located $80 \mathrm{~km}$ northwest of The Granites goldfield. More than 40 deposits are located within a $15 \mathrm{~km}$ long, northeast-trending zone locally known as the Tanami Mine Corridor. Mineralisation in the Tanami goldfield is hosted by an alternating succession of basalt and mudstone belonging to the Mount Charles Formation (Fig. 2). Gold occurs in quartz-carbonate veins associated with sericite-pyrite alteration. The ore shoots range from 1 to $20 \mathrm{~m}$ thick, 20 to $300 \mathrm{~m}$ in length and 10 to $70 \mathrm{~m}$ vertical extent. Higher gold 


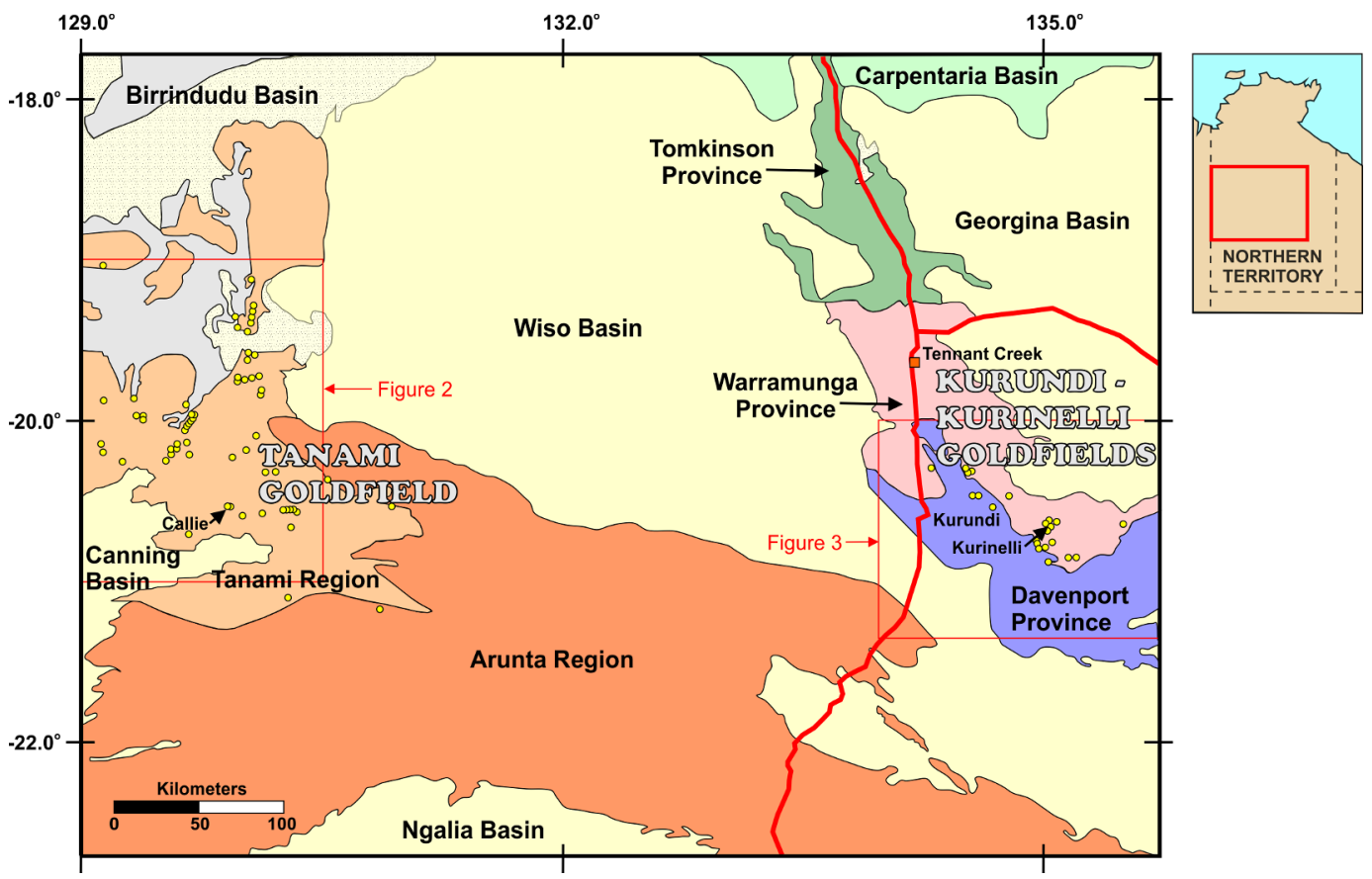

Fig. 1. Map of the geological regions in the centre of the Northern Territory, Australia. The yellow dots depict gold mines and prospects in the Tanami goldfield and the Kurundi-Kurinelli goldfields, respectively. The red lines show the major highways in this region. All data were obtained from the Spatial Territory Resource Information Kit for Exploration (STRIKE) web application provided by the Northern Territory Geological Survey. The light red boxes indicate the locations within the Northern Territory of Figs. 2 and 3. (For interpretation of the references to colour in this figure legend, the reader is referred to the web version of this article.)

grades occur adjacent to ore shoot boundaries. The main gangue minerals are calcite, siderite and quartz and pyrite is the main sulphide, comprising $5-20 \%$ of vein composition.

The Groundrush gold deposit is located about $40 \mathrm{~km}$ northeast of the Tanami goldfield and lies near the Frankenia granitic 'dome'. The deposit sits within a $90-160 \mathrm{~m}$ thick dolerite sill intruding metagreywacke of the Ferdies Member, Dead Bullock Formation (Fig. 2). Mineralised lodes are $10-30 \mathrm{~m}$ wide and consist of anastomosing zones of northeast-trending quartz veins dipping $70-80^{\circ}$ and striking west. Gold occurs as free metal, or is associated with arsenopyrite and to a lesser extent, with pyrite and pyrrhotite.

Significant deposits in the Western Australian part of the Tanami Region include Coyote, and Kookaburra (Bagas et al., 2014; Ahmad et al., 2013). At least three sets of quartz veins are recognised at the Coyote deposit but only the first two sets are mineralised. Localised alteration assemblages accompanying these vein sets include 1) quartz-sericite-pyrite-chlorite, silica-dolomite spotting and veining, 2) uncommon quartz-K-feldspar, graphite, and 3) chlorite-biotite. Only the chlorite-biotite assemblage can be related to the auriferous veins, although some may be related to late carbonate-bearing veinlets (Bagas et al., 2009). At Kookaburra, gold is associated with quartz-carbonate \pm pyrite \pm arsenopyrite veins with variable amounts of sericite, $\mathrm{K}-$ feldspar and marcasite, and minor to trace quantities of biotite, amphibole, apatite, sphalerite, and pyrrhotite. The Buccaneer deposit was the first intrusion-hosted gold system discovered in the Tanami region (Bagas et al., 2014). It is hosted in the southern part of the ca 1795 Ma Twin Bonanza Porphyry, which also hosts the Cypress gold prospect in the north.

\subsection{Warramunga Province}

The Proterozoic Warramunga Province forms the central part of the Tennant Region, north and northwest of the Davenport Province and south of the Tomkinson Province (Donnellan, 2013; Fig. 3). To the east and west, the province extends subsurface beneath the Phanerozoic Georgina and Wiso basins, respectively. The oldest rocks of the
Warramunga Province predate the ca 1850 Ma Tennant Event, and are divided into the Warramunga Formation, and the correlative Junalki Formation and Woodenjerrie beds. These rocks are overlain in the south by the Hatches Creek Group in the Davenport Province, but in the north, they are overlain by the Tomkinson Creek Group in the Tomkinson Province (not shown in Fig. 3).

Geochronological data indicate that there were four episodes of felsic volcanism in the Warramunga Province. These span the time interval between Junalki Formation volcanism (ca $1860 \mathrm{Ma}$ ) and the end of Ooradidgee Group time (ca $1810 \mathrm{Ma}$ ). Hoatson et al. (2007) assigned mafic magmatism in the Warramunga Province to three magmatic events. These are the ca 1850 Ma Mumbilla Event, the 1840-1820 Ma Edmirringee Event and the 1820-1800 Ma Mount Hay Event. The Mount Hay Event includes gabbro and dolerite sills that intrude the Kurinelli area of the southern Warramunga Province.

Compared to the Tanami region, the Kurundi - Kurinelli goldfields in the Warramunga Province are rather poorly endowed. Official production records indicate that only $25 \mathrm{~kg}$ of gold was produced from this region between 1926 and 1995 (Ahmad et al., 2009). Gold is present in quartz veins occupying bedding parallel faults or shears within sediment - dolerite contact zones, or within sedimentary and volcanic rocks of the Ooradidgee Subgroup. In the Kurundi goldfield (Fig. 3), gold is present in bedding-parallel quartz veins, which are 1-3 m wide and up to $200 \mathrm{~m}$ long. These veins are hosted in a variety of lithologies including quartz sandstone and shale of the Kurinelli Sandstone (Great Davenport, Power of Wealth, Aztec and Priesters); acid volcanics of the Epenarra Volcanics (Millars) and the Junalki Formation (Opengidgi); basalt of the Edmirringee Volcanics (Kurundi); sandstones of the Taragan Sandstone (Cairns); granophyre and quartz-feldspar porphyry (Davidsons). In the Kurinelli goldfield (Fig. 3) the gold is generally located in northeasterly-trending, quartz-filled shear zones within dolerite/gabbro and sandstone (Rooneys Formation), or at the dolerite sediment contact. Quartz veins, emplaced subparallel to bedding, are $0.2-2 \mathrm{~m}$ wide and can be traced for up to $200 \mathrm{~m}$ along strike. Mineralisation is erratic and occurs as fine- to coarse-grained native gold, in places associated with chalcopyrite and pyrite. 


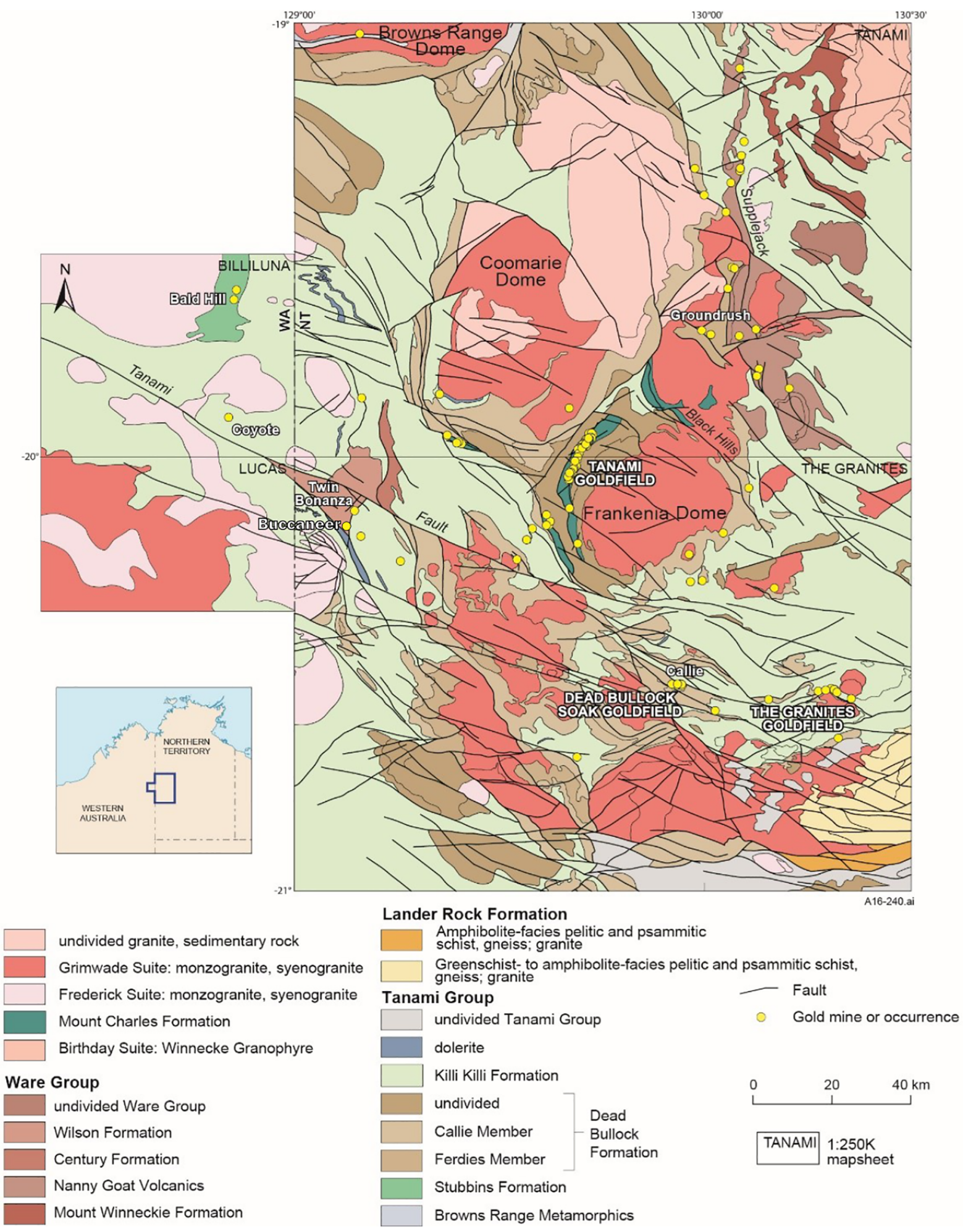

Fig. 2. Bedrock geology and gold mines and gold occurrences of the Tanami region (from Ahmad et al., 2013). The yellow dots depict gold occurrences. (For interpretation of the references to colour in this figure legend, the reader is referred to the web version of this article.)

\section{Previous fluid inclusion studies}

\subsection{Fluid inclusions in the Tanami region}

Mernagh and Wygralak (2007) have carried out fluid inclusion studies on the major gold deposits and prospects in the Tanami Region. Six main types of inclusions, based on their phase proportions at room temperature, were identified in this study and are listed below:
Type A. Primary, $\mathrm{CO}_{2}$-rich inclusions. They are very abundant and contain a $\mathrm{CO}_{2}$-rich liquid phase or $\mathrm{CO}_{2}$-rich liquid + vapour phases. They may also contain small amounts of $\mathrm{CH}_{4}$ or $\mathrm{N}_{2}$ and a minor aqueous phase.

Type B. Primary, two-phase, $\mathrm{CH}_{4}\left( \pm \mathrm{CO}_{2}\right)+\mathrm{H}_{2} \mathrm{O}$ inclusions. These inclusions are not as abundant and contain $10-30 \mathrm{vol} \%, \mathrm{CH}_{4}$-rich vapour.

Type C. Primary, monophase, $\mathrm{CH}_{4} \pm \mathrm{N}_{2} \pm \mathrm{CO}_{2}$ vapour inclusions. These inclusions are quite rare and can be distinguished from Type A inclusions by their $\mathrm{CH}_{4}$ - or $\mathrm{N}_{2}$-rich nature. 


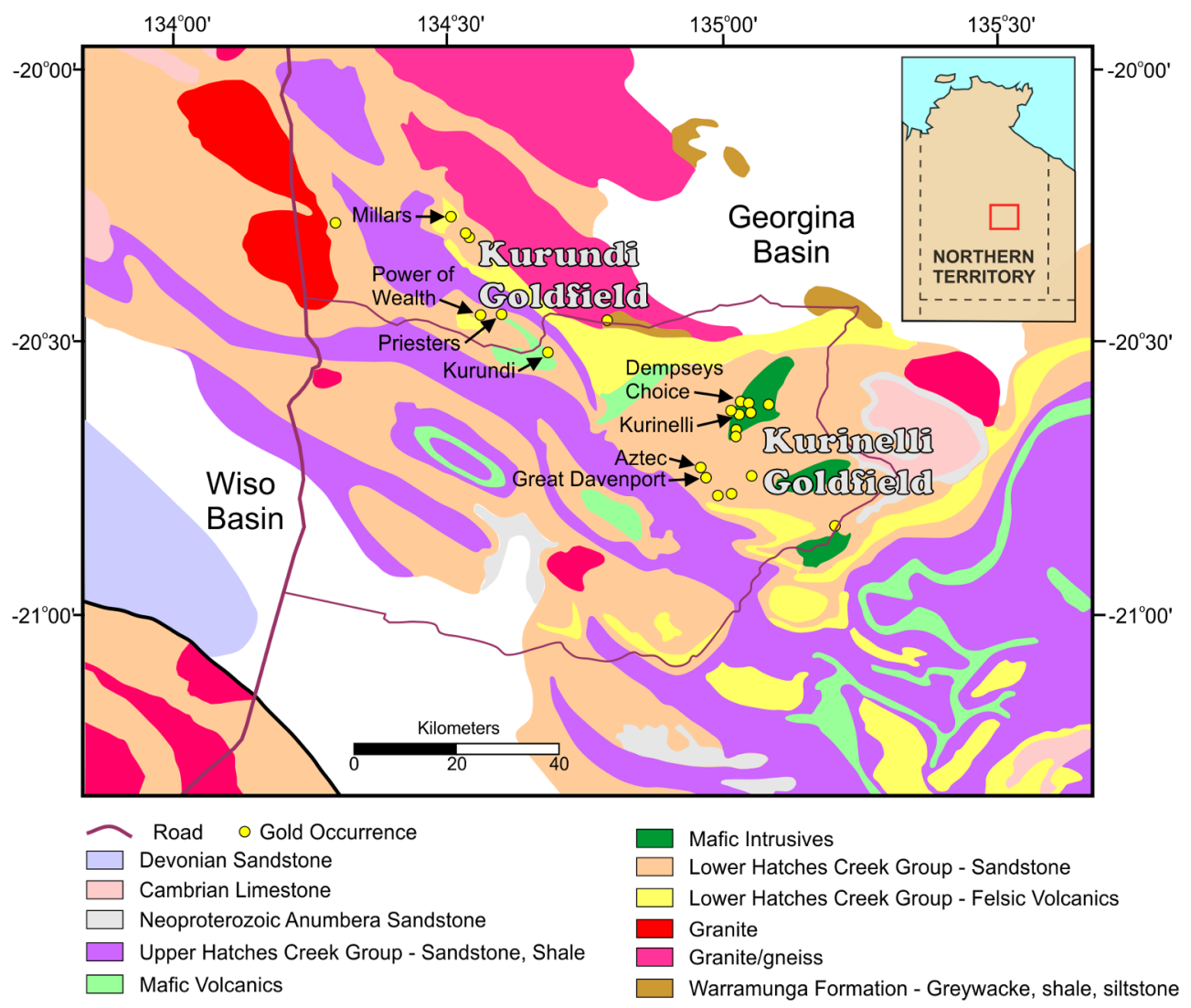

Fig. 3. Interpreted solid geology map of the Kurundi and Kurinelli Goldfields in the Northern Territory, Australia. The yellow dots depict gold occurrences. (For interpretation of the references to colour in this figure legend, the reader is referred to the web version of this article.)

Type D. Two-phase, aqueous inclusions. They contain 5-15 vol\% vapor, and are abundant in all stages of veining and may be primary or secondary.

Type E. Rare, secondary, aqueous inclusions with one or more daughter minerals. They typically contain halite and may also contain a vapour bubble. No gases were detected by Raman spectroscopy in the vapour bubble.

Type F. Secondary, two-phase brine inclusions. These are generally large, irregular, $\mathrm{CaCl}_{2}$-bearing inclusions with $5-15$ vol\% vapour. Once again, no gases were detected by Raman spectroscopy in the vapour bubble.

Only the primary fluid inclusions associated with mineralisation will be considered and discussed in this paper.

The ore bearing quartz veins in the Tanami region typically contain coexisting Type A and D inclusions (Table 1). Microthermometric data indicate that the gold deposits formed over a range of depths and at homogenisation temperatures from 184 to $430{ }^{\circ} \mathrm{C}$. No pressure corrections were applied to these temperatures. The Groundrush deposit formed at the greatest temperatures and depths $\left(260-430^{\circ} \mathrm{C}\right.$ and $\left.\leq 11 \mathrm{~km}\right)$, whereas deposits in the Tanami goldfield formed at the lowest temperatures $\left(184-359^{\circ} \mathrm{C}\right)$ and at the shallowest depths $(1.5-5.6 \mathrm{~km})$. Other deposits (e.g., The Granites, Callie, and Coyote) formed at depths between those of the Tanami goldfield and the Groundrush deposit and at temperatures ranging from 240 to $360^{\circ} \mathrm{C}$. Furthermore, the more deeply formed deposits were found to be enriched in $\mathrm{CH}_{4}$ (with up to $85 \mathrm{~mol} . \% \mathrm{CH}_{4}$ in the vapour phase) and higher level deposits were enriched in $\mathrm{CO}_{2}\left(85-100 \mathrm{~mol} \% \mathrm{CO}_{2}\right.$ in the vapour phase). Fluids from deposits hosted mainly by sedimentary rocks generally also contained appreciable quantities of $\mathrm{N}_{2}$ ( $\leq 100 \mathrm{~mol} . \%$ in the vapour phase). Calculated $\delta^{18} \mathrm{O}$ data for the ore fluids indicated a magmatic or mixed magmatic/metamorphic source for the ore fluids in the Tanami Region (Mernagh and Wygralak, 2007).

Interpretation of the fluid inclusion, alteration, and structural data suggests that mineralisation may have occurred via a number of processes (Mernagh and Wygralak, 2007). Gold occurs in veins associated with brittle fracturing and other dilational structures, but in the larger deposits, there is also an association with iron-rich rocks or carbonaceous sediments, suggesting that both structural and chemical controls are important. The major mineralisation process appears to be fluid immiscibility (i.e. boiling/effervescence) as indicated by the coexistence of vapour -rich (Type A) and liquid-rich (Type D) inclusions in fluid inclusion assemblages (FIAs) in the veins (Mernagh and Wygralak, 2007). However, the presence of pyritic alteration haloes around the quartz veins in some deposits may indicate that desulfidation by fluid-rock interaction may also be a significant ore deposition mechanism for these deposits. The pyritic alteration is generally more prevalent in the higher crustal-level deposits.

\subsection{Fluid inclusions in the Warramunga Province}

Wygralak and Mernagh (2008) conducted fluid inclusion studies on the major gold deposits and prospects in the Warramunga Province. They recognised two types of fluid inclusions, Types $\mathrm{A}$ and $\mathrm{D}$, in this region (Table 1). The Type $\mathrm{A}, \mathrm{CO}_{2}$-rich fluid inclusions have salinities $<7 \mathrm{wt} \%$ $\mathrm{NaCl}$ eq. while the coexisting Type $\mathrm{D}$, aqueous inclusions have salinities up to $10 \mathrm{wt} \% \mathrm{NaCl}$ eq. These FIAs homogenised to liquid over the temperature range $400-440^{\circ} \mathrm{C}$ and by analogy with other OGDs (Ridley and Diamond, 2000), these inclusions are thought to represent the main mineralising fluid in this region. The second type of FIAs contained only Type D, two-phase, aqueous inclusions which homogenised to liquid over a broad temperature range of $140-340{ }^{\circ} \mathrm{C}$. This fluid has high salinity ranging from 18 to $22 \mathrm{wt} \%$ $\mathrm{NaCl}$ eq. and the lack of gas-rich inclusions in these FIAs indicate that they may have resulted from the trapping of a later basinal brine.

\section{Analytical methods}

\subsection{Fluid inclusion petrography}

This study uses the same samples from high-grade ore zones as previously reported in Mernagh and Wygralak (2007) and Wygralak 
Table 1

A summary of microthermometric and laser Raman microprobe data for fluid inclusions for selected deposits in the Tanami and Kurundi - Kurinelli goldfields.

\begin{tabular}{|c|c|c|c|c|c|c|}
\hline Deposit & Inclusion Type $^{\mathrm{a}}$ & $\mathrm{X}_{\mathrm{CO} 2}(\text { vap) })^{\mathrm{b}, \mathrm{c}}$ & $\mathrm{X}_{\mathrm{N} 2}$ (vap) & $\mathrm{X}_{\mathrm{CH} 4}$ (vap) & $\mathrm{Wt} \% \mathrm{NaCl}$ equiv & $\mathrm{T}_{\mathrm{h}}\left({ }^{\circ} \mathrm{C}\right)$ \\
\hline \multicolumn{7}{|l|}{ Tanami Goldfield } \\
\hline Callie & A & $0.0-1.0(0.81)$ & $0.0-0.76(0.17)$ & $0.0-0.12(0.02)$ & $3.8-7.3(6.9)$ & 254 to 326 (311) \\
\hline Callie & $\mathrm{D}$ & ND & ND & ND & $5.1-20.0(14.6)$ & 209 to 404 (274) \\
\hline Groundrush & B & $0.15-0.87(0.45)$ & $0.0-0.27(0.03)$ & $0.13-0.85(0.51)$ & $1.2-13.9(7.5)$ & 213 to 490 (346) \\
\hline Groundrush & $\mathrm{D}$ & ND & ND & ND & $0.2-10.4(6.9)$ & 161 to 277 (207) \\
\hline Coyote & A & $0.73-1.0(0.79)$ & $0.0-0.09(0.06)$ & $0.0-0.20(0.07)$ & $0.0-6.7(2.1)$ & 185 to 408 (308) \\
\hline Coyote & B & $0.0-0.18(0.02)$ & $0.0-0.38(0.08)$ & $0.62-1.0(0.90)$ & $0.0-12.5(2.7)$ & 245 to 389 (325) \\
\hline Coyote & $\mathrm{C}$ & $0.47-0.59(0.5)$ & $0.3-0.63(0.39)$ & $0.0-0.24(0.11)$ & - & 312 to 417 (359) \\
\hline Coyote & $\mathrm{D}$ & ND & ND & ND & $1.1-11.8(5.5)$ & 183 to 434 (258) \\
\hline \multicolumn{7}{|c|}{ Kurundi - Kurinelli goldfield } \\
\hline Dempseys Choice & A & $0.15-1.0(0.67)$ & $0.0-0.41(0.10)$ & $0.0-0.22(0.02)$ & - & 360 to 445 (399) \\
\hline Dempseys Choice & $\mathrm{D}$ & ND & ND & ND & 2.0 to $22.1(7.8)$ & 180 to $313(243)$ \\
\hline Kurinelli & A & $0.29-0.97(0.86)$ & $0.0-0.13(0.08)$ & $0.0-0.29(0.06)$ & - & 366 to $419(406)$ \\
\hline Kurinelli & $\mathrm{D}$ & ND & ND & ND & 16.9 to $19.4(18.0)$ & 109 to $275(178)$ \\
\hline Power of Wealth & A & $0.45-1.0(0.91)$ & $0.0-0.36(0.08)$ & $0.0-0.16(0.03)$ & - & 205 to $357(340)$ \\
\hline Power of Wealth & $\mathrm{D}$ & ND & ND & ND & 1.7 to 11.5 (9.2) & 130 to $428(323)$ \\
\hline Kurundi & A & $0.64-0.9(0.84)$ & $0.0-0.08(0.05)$ & $0.08-0.22(0.11)$ & - & 154 to $418(335)$ \\
\hline Kurundi & $\mathrm{D}$ & ND & ND & ND & 1.7 to $11.1(8.8)$ & 186 to 299 (232) \\
\hline
\end{tabular}

a See text for definitions.

b Mole fraction of $\mathrm{CO}_{2}, \mathrm{~N}_{2}$ and $\mathrm{CH}_{4}$ in the vapour phase as determined by laser Raman microprobe analysis.

c The quoted figures represent the range of the data and the average value is given in parentheses.

and Mernagh (2008). These previous studies have carefully determined the vein paragenesis at each deposit and only mineralised quartz and/or quartz-carbonate veins were used in this study. The majority of fluid inclusions in the samples were small $(<20 \mu \mathrm{m}$ and mostly $<5 \mu \mathrm{m})$. The vein quartz typically contained densely packed arrays of fluid inclusions but, in this study, care was taken to select growth zones containing primary and pseudosecondary fluid inclusion assemblages (FIA), as defined by Goldstein and Reynolds (1994). Examples of twophase, aqueous FIAs from the Kurinelli deposit and $\mathrm{CO}_{2}$-bearing, vapour-rich FIAs from the Callie deposit are shown in Fig. 4.

\subsection{Fluid inclusion microthermometry}

As discussed above, extensive microthermometry has already been done on these samples (Mernagh and Wygralak, 2007; Wygralak and Mernagh, 2008). Additional fluid inclusion studies were carried out on the samples selected for LA-ICPMS analysis to obtain accurate salinities of the selected FIAs for the standardisation of the LA-ICPMS data. The new data is reported in the Electronic Supplementary Material. Microthermometry was carried out on a Linkam MDSG600 heating/ cooling stage which was calibrated with synthetic $\mathrm{H}_{2} \mathrm{O}$ and $\mathrm{H}_{2} \mathrm{O}-\mathrm{CO}_{2}$ fluid inclusion standards. A heating rate of $2{ }^{\circ} \mathrm{C} / \mathrm{min}$ was used up to $30^{\circ} \mathrm{C}$ and then a heating rate of $5^{\circ} \mathrm{C} / \mathrm{min}$ was used at higher temperatures. After calibration the stage was accurate to $\pm 0.2^{\circ} \mathrm{C}$ below $30^{\circ} \mathrm{C}$ and $\pm 2.0^{\circ} \mathrm{C}$ above $30^{\circ} \mathrm{C}$. All phase transitions were carefully measured by taking photos at approximately one second intervals to accurately determine the temperature of the phase transitions.

\subsection{Cathodoluminescence studies}

CL images were obtained from a JEOL JSM-7800F Field Emission Scanning Electron Microprobe with the MonoCL4 detector from Gatan Inc. and a $10 \mathrm{k} \mathrm{eV}$ beam.

\subsection{LA-ICPMS analysis of the fluid inclusions}

The analyses were conducted at the State Key Laboratory of Ore Deposit Geochemistry, IGCAS by using the Agilent 7900 ICP-MS, which is combined with a GeoLasPro $193 \mathrm{~nm}$ ArF excimer laser and with synthetic fluid inclusions to monitor the accuracy (Lan et al., 2017a,b). The instruments, analytical conditions and reference materials used for analysis are listed in Table 2. In order to avoid premature fracturing of the host quartz in this study, a stepwise drilling procedure was used. Firstly the host quartz were pre-drilled at lower repetition rate and small spot size, and then with relative high repetition rate and big spot size (depending on the fluid inclusion size) to open and ablate the entire inclusion, followed by another ablation with bigger spot size to obtain the trace element concentration in the quartz matrix. Generally, a hole of $10 \mu \mathrm{m}$ in diameter was pre-drilled with a $4 \mathrm{~Hz}$ repetition rate in the quartz. Then a hole of $16 \mu \mathrm{m}$ was drilled in the same spot with a $4 \mathrm{~Hz}$ repetition rate, followed by hole of $24 \mu \mathrm{m}$ with a $10 \mathrm{~Hz}$ repetition rate to open and ablate the whole inclusions. Then to obtain the trace element concentration in the quartz matrix, this was followed by another hole of $32 \mu \mathrm{m}$ with a $10 \mathrm{~Hz}$ repetition rate. A comparison of this new method of determining the composition of the quartz matrix with conventional methods shows agreement for all elements is better than $20 \%$ (for $\mathrm{Na}, \mathrm{K}, \mathrm{Ca}$ and $\mathrm{Mg}$ the differences are $<5 \%$ ), which is acceptable for fluid inclusion analyses. This method has the advantage of providing a more accurate composition of the quartz matrix around the inclusion, whereas separate ablations carried out before or after fluid inclusion analysis are prone to contamination issues.

The adoption of this stepwise laser drilling procedure greatly increased the number of successful ablations with a quantifiable ICPMS signal. As reported by Fusswinkel et al. (2017), the most important criterion was a stable and steady ablation of the host quartz for several seconds before and after inclusion breach, without fracture formation (leakage of fluid) at the bottom of the ablation pit or explosive opening of inclusions (spallation), because both processes may lead to incomplete sampling of inclusion contents. Fracturing of quartz can result in partial fluid leakage into the sample along newly formed crack surfaces extending out from the ablation pit, which results in very long, drawn out signals with low intensity. Spallation usually results in uncontrolled opening of the inclusion cavity and explosive fluid release, which may not ensure complete vaporisation of inclusion contents (Fig. 5).

The SILLS software package (Guillong et al., 2008) was used for LAICPMS data reduction. All elements were quantified against NIST SRM610 as the external standard. Absolute concentration values were then calculated by internal standardisation against $\mathrm{Na}$ concentrations determined by microthermometry. Most fluid types contained significant amounts of other cations as well, so that the $\mathrm{NaCl}$ equivalent salinity ( $\mathrm{NaCl}$ eq.) is not identical to the true fluid salinity. However, true Na concentration for internal standardisation can be reasonably 

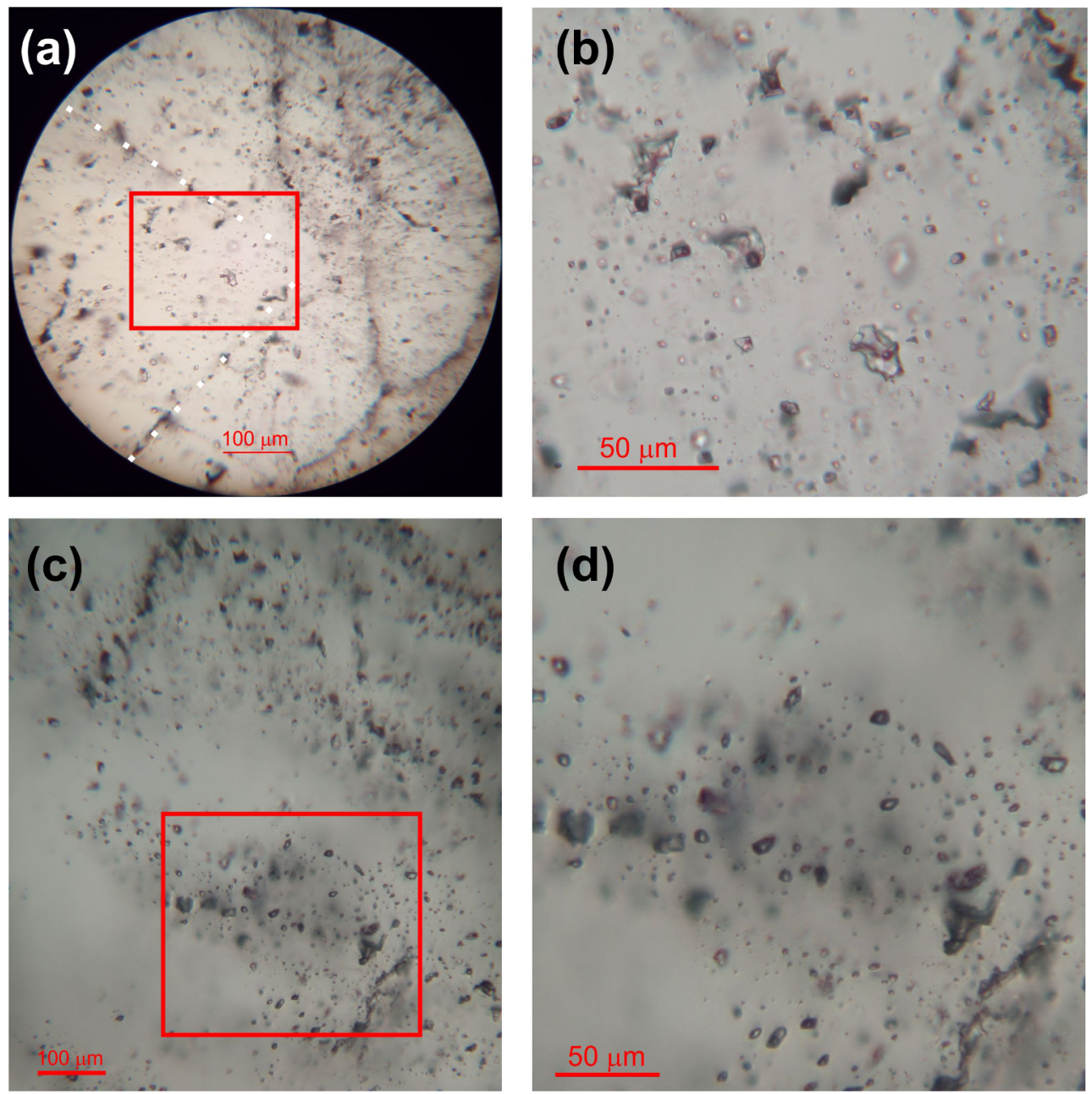

Fig. 4. Examples of Fluid Inclusion Assemblages (FIAs) showing (a) two-phase aqueous inclusions from the Kurinelli deposit. The white dots outline a growth zone in quartz, (b) an enlargement of the area within the red square in (a) showing an FIA of aqueous inclusions, (c) Vapour-rich fluid inclusions from the Callie Deposit, and (d) an enlargement of the area within the red square in (c) showing an FIA of vapour-rich, $\mathrm{CO}_{2}$-bearing fluid inclusions. (For interpretation of the references to colour in this figure legend, the reader is referred to the web version of this article.)

well approximated by charge balancing using cation/chlorine ratios from LA-ICPMS signals, as described by Allan et al. (2005). Comparisons with synthetic inclusions (Allan et al., 2005; Zhou et al., 2016) show that this method produces acceptable results. Limits of detection were calculated using Eq. (6) in Pettke et al. (2012), which yields concentration of an element at the $95 \%$ confidence level. The method is implemented in the SILLS software package.

\section{Results}

\subsection{Cathodoluminescence studies}

In this study we have used cathodoluminescence (CL) to better understand the timing of fluid inclusion trapping in the samples that were selected for LA-ICPMS analysis. Fig. 6 shows the extra information

Table 2

Summary of instruments, analytical conditions and reference materials used for the LA-ICPMS measurements.

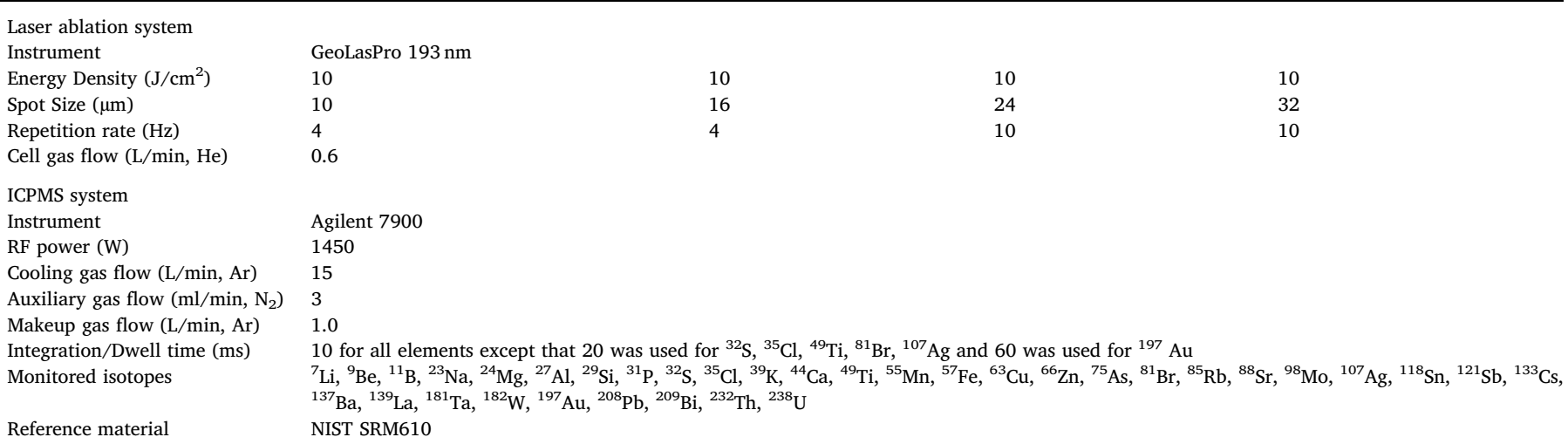




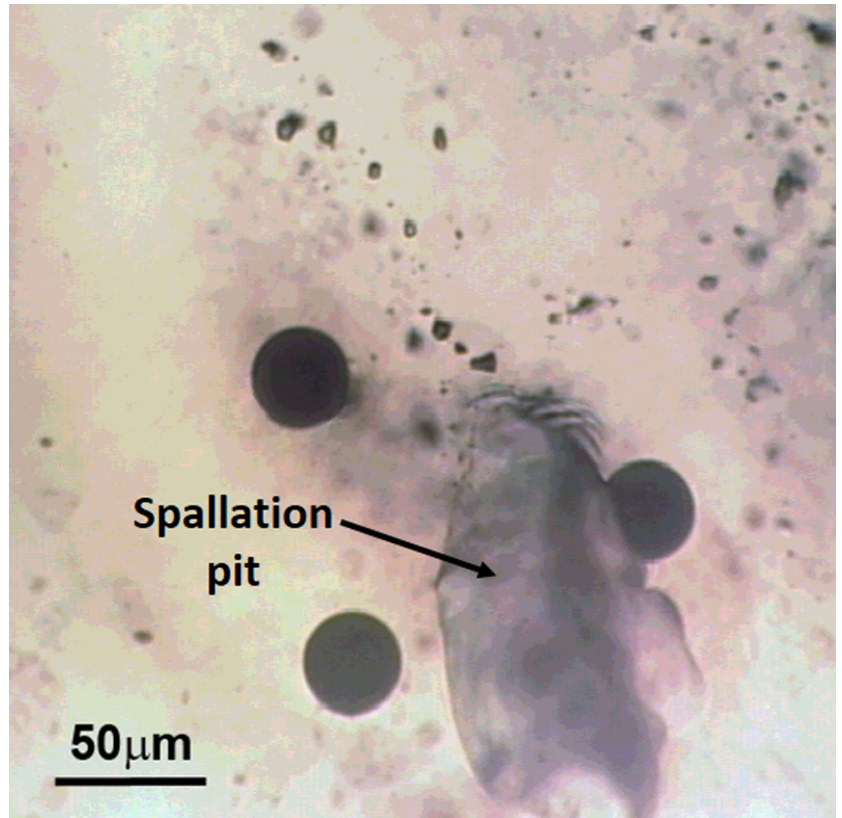

Fig. 5. An example of vein quartz after ablation with $193 \mathrm{~nm}$ excimer laser showing three successful, perfectly round holes, each $32 \mu \mathrm{m}$ in diameter. A fourth laser analysis in between the previous holes produced a large spallation pit and this analysis was subsequently rejected.

that can be obtained from the CL image of a quartz vein from the Groundrush deposit. In Fig. 6(a) the sample is viewed in ordinary transmitted light and contains a densely packed array of inclusions along with some trails of secondary inclusions but no other information on the relative timing of inclusion trapping is apparent in this image. However, the CL image is remarkably more detailed (Fig. 6(b)). As shown in Fig. 6(b), the dark grey quartz (Q1) is the earliest phase which appears to have been fractured and infilled with the light grey quartz (Q2). This latter quartz also has alternating dark and light bands at approximately $45^{\circ}$ which may represent growth banding. Finally, the whole sample is cut by a large number of thin, anastomosing veinlets of black quartz (Q3).

Microthermometry was carried out on selected inclusions from both the Q1 and Q2 quartz in this sample prior to LA-ICPMS analyse. The pits left after laser ablation are outlined with red circles in Fig. 6(b) and the salinity of these inclusions (in wt $\% \mathrm{NaCl}$ eq.) is shown next to the circles. The data show that the inclusions studied by microthermometry in the early Q1 quartz have salinities of $17.5-17.7 \mathrm{wt} \% \mathrm{NaCl}$ eq. which is slightly lower than inclusions in the later Q2 quartz, which range from 17.7 to $18.2 \mathrm{wt} \% \mathrm{NaCl}$ eq. but as only a few inclusions from each zone were analysed, the result remains equivocal.

Unfortunately, it was not possible to distinguish different generations of quartz in the other deposits as they did not show any significant differences in the CL images. This is similar to quartz in orogenic Au deposits which typically generate a dull grey, homogenous CL response and mottled textures (Rusk, 2012).

\subsection{Fluid inclusion LA-ICPMS}

As discussed above we imposed strict quality principles to define successful ablations. Analyses were only accepted when we observed steady ablation of the host quartz for at least several seconds before and after opening the fluid inclusion (Fig. 7). The results from some fluid inclusions were rejected because of their small size or because they were located too close to the surface of the wafer, which makes them more susceptible to spallation. An example of a good LA-ICPMS analysis of a two-phase, aqueous inclusion is shown in Fig. 7(a). The stepwise opening of the laser hole is demonstrated by the alternating $\mathrm{Si}$ intensities. When the inclusion is opened, all element signals increase in synchronisation with the Na peak, which is used for internal standardization. The composition of the host quartz is then determined by a subsequent ablation of the same hole with a $32 \mu \mathrm{m}$ diameter laser beam. An example of a good LA-ICPMS analysis of a $\mathrm{CO}_{2}$-rich inclusion is shown in Fig. 7(b). Here, the same stepwise opening procedure is used but when the inclusion is breached only a small increase in the Na intensity is observed. All other elements are below detection limits. Therefore, only LA-ICPMS analyses of the two-phase aqueous inclusions are included in this study.

All the accepted LA-ICPMS data from the two-phase, aqueous inclusions show elevated concentrations of $\mathrm{Na}, \mathrm{K}, \mathrm{As}, \mathrm{B}, \mathrm{Rb}, \mathrm{Sr}$ and $\mathrm{Sb}$. The average element concentrations of successfully analysed FIAs for each ore deposit are plotted in Fig. 8. The full dataset of individual measurements is available as Electronic Supplementary Material. It can be seen from Fig. 8 that there are systematic differences between the different ore deposits, especially differences between the doleritehosted Groundrush deposit and the Callie and Coyote deposits in the Tanami goldfield. The Groundrush deposit has higher concentrations of $\mathrm{Mg}$ while the other deposits have a higher concentration of $\mathrm{B}, \mathrm{Cu}$, and $\mathrm{Zn}$. In the Kurundi - Kurinelli goldfields, the Power of Wealth and Kurundi deposits have lower salinity, and hence, lower Na concentration than the other deposits. The Kurundi deposit also has high Fe, As and $\mathrm{Sb}$ concentrations. This may reflect the fact that the quartz veining is hosted by basalt of the Edmirringie Volcanics. The Kurinelli and Power of Wealth deposits have relative low concentrations of $\mathrm{Mg}$ compared to other deposits, which may indicate that the fluids have not interacted with mafic volcanics in these deposits.

The ratio of $\mathrm{Na} / \mathrm{K}$ is of interest because of its potential as a geothermometer. If the fluids equilibrated with two feldspars, this ratio
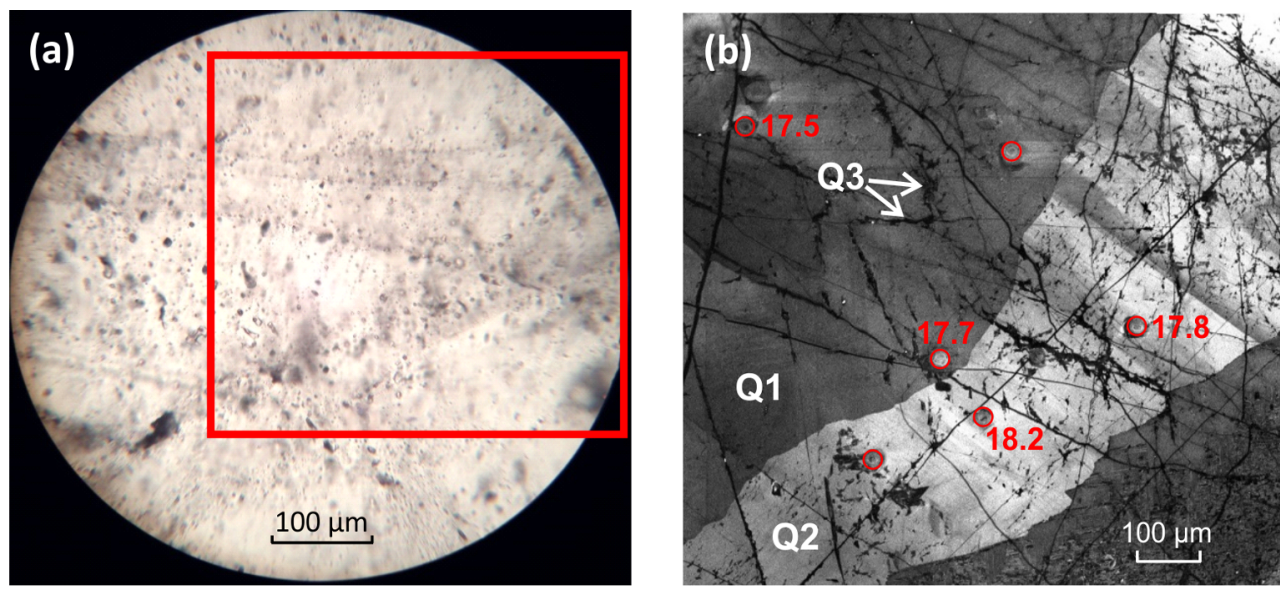

Fig. 6. (a) Transmitted light photograph of a quartz vein from the Groundrush deposit, (b) Cathodoluminescence image of the area inside the red box in Fig. 6(a) showing early dark grey quartz (Q1) and later light grey quartz (Q2) both crosscut by late black quartz (Q3). The red circles mark the pits from the laser ablation analyses. The red numbers indicate the salinity of selected inclusions as determined by microthermometry. See text for details. (For interpretation of the references to colour in this figure legend, the reader is referred to the web version of this article.) 


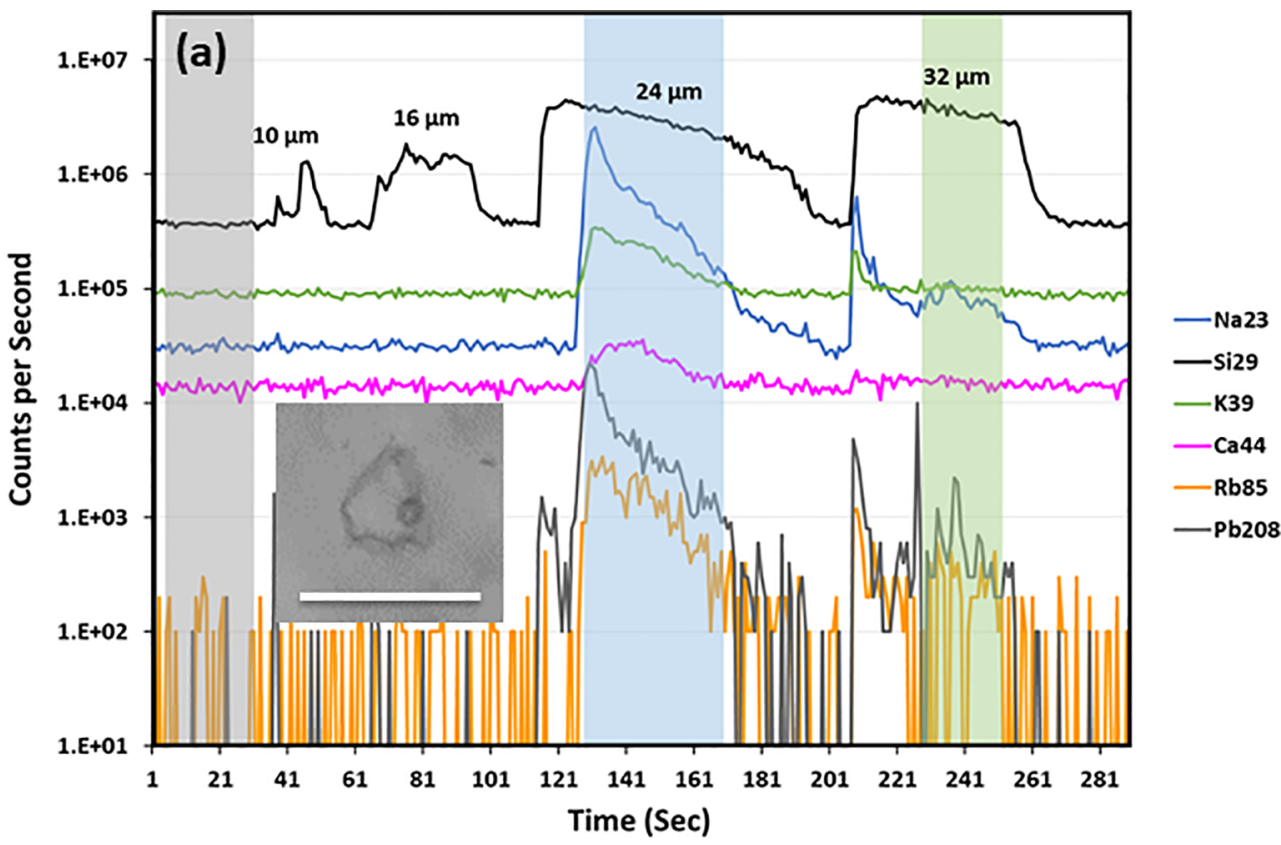

Fig. 7. Time-resolved fluid inclusion LAICPMS count rate spectra demonstrating (a) a good ablation of a two-phase, aqueous fluid inclusion. The inset shows a picture of the aqueous inclusion before ablation (scale bar $=20 \mu \mathrm{m}$ ), and (b) a good ablation of a $\mathrm{CO}_{2}$-rich fluid inclusion. Note that, except for $\mathrm{Si}$ and $\mathrm{Na}$, all elements are below detection limits. The inset shows a picture of the $\mathrm{CO}_{2}$-rich inclusion before ablation (scale bar $=20 \mu \mathrm{m}$ ). In both figures, the four elevated regions in the ${ }^{29} \mathrm{Si}$ signal (black line) show the stepwise laser ablation cycles with the $10,16,24$ and $32 \mu \mathrm{m}$ beam diameters. The grey shaded region is the interval used for background counting, the blue region is the interval used for the inclusion signal, and the green region is the interval used for the host matrix. See text for details. (For interpretation of the references to colour in this figure legend, the reader is referred to the web version of this article.)

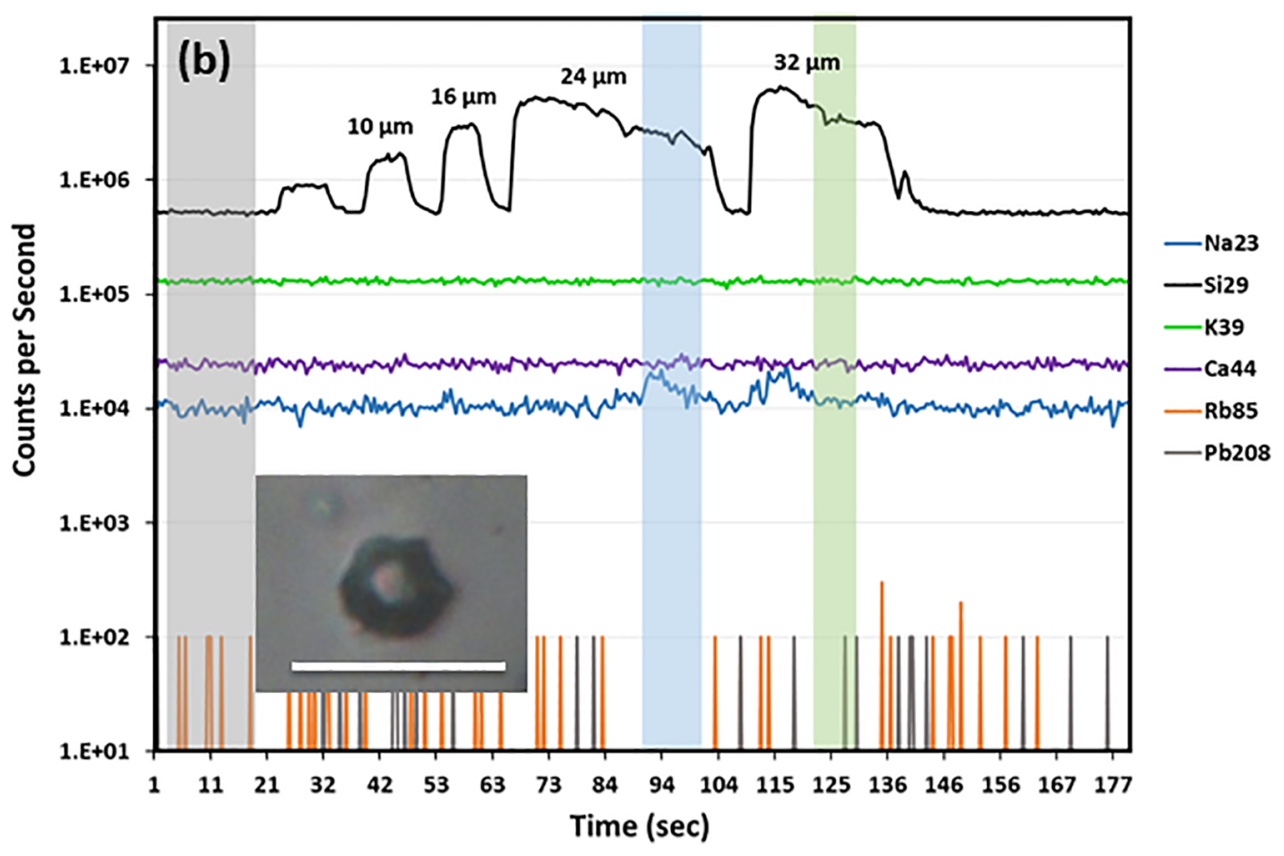

should be a function of temperature, with lower ratios at higher temperature (Orville, 1963; Rusk et al., 2004). Most of the deposits have a fairly constant molar $\mathrm{Na} / \mathrm{K}$ ratio, which ranges from 3.3 to 5.7 . However, the Kurundi deposit has a much lower ratio of 1.6. The fluid inclusion data from the Kurundi deposit (Wygralak and Mernagh, 2008) indicate that this deposit actually formed at slightly lower temperatures (average $\mathrm{T}_{\mathrm{h}}=232^{\circ} \mathrm{C}$ ) than other deposits in this region (average $\mathrm{T}_{\mathrm{h}}$ from 279 to $326^{\circ} \mathrm{C}$ ). Therefore, we conclude that the fluid in this deposit was not in equilibrium with the two feldspars.

A comparison of the fluid composition across all the deposits shows, in general, that the fluids are richer in $\mathrm{Na}$ and $\mathrm{Ca}$ and have lower concentrations of $\mathrm{K}$. Magnesium concentrations are generally much lower in the Kurundi - Kurinelli goldfields, perhaps reflecting a lower amount of mafic rocks in this region. Iron concentrations vary by several orders of magnitude and may reflect the different host rocks (i.e. mafic or arenaceous) of these deposits. Average Rb:Sr ratios for individual FIA vary considerably in each goldfield. In the Tanami goldfield the $\mathrm{Rb}: \mathrm{Sr}$ ratios range from 0.073 to 0.500 while in the Kurundi - Kurinelli goldfields they range from 0.095 to 1.180

Gold was consistently below the limits of detection (0.5 to $10.0 \mu \mathrm{g}$ / $\mathrm{g}$ ) for all fluid inclusions analysed in this study. Reliable data for $\mathrm{Au}$ concentrations in orogenic fluids are still very scarce. Garofalo et al. (2014) report concentrations of $0.5 \mu \mathrm{g} / \mathrm{g}$ to $5 \mu \mathrm{g} / \mathrm{g}$ for the Sigma gold deposit in the Abitibi Greenstone Belt, Canada, and Fusswinkel et al. (2017) report Au concentrations up to $0.6 \mu \mathrm{g} / \mathrm{g}$ for the Pampalo OGD in Finland.

Large et al. (2016) have shown that the sources of fluids can be inferred from their trace element composition and so we have compared the trace element ratios of the LA-ICPMS data from the two different goldfields in Fig. 9. Both goldfields show a similar spread in the range of $\mathrm{Sr}-\mathrm{B}-\mathrm{Rb}$ ratios which trend from the B-rich magmatic vapour field to the Sr-rich sedimentary influenced field (Fig. 9a and b). In comparison to the other deposits, samples from the Kurinelli deposit are enriched in $\mathrm{Sr}$ and plot mostly in the sedimentary influenced field. The 
(a)

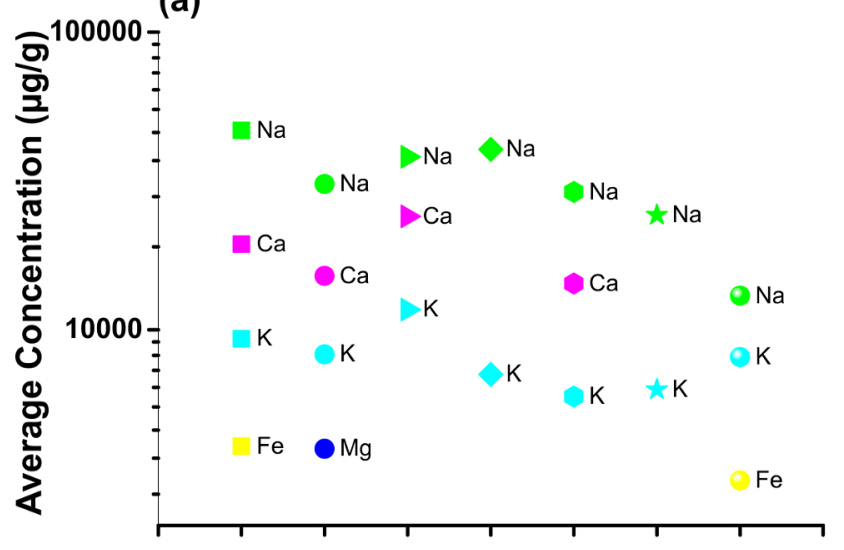

(b)

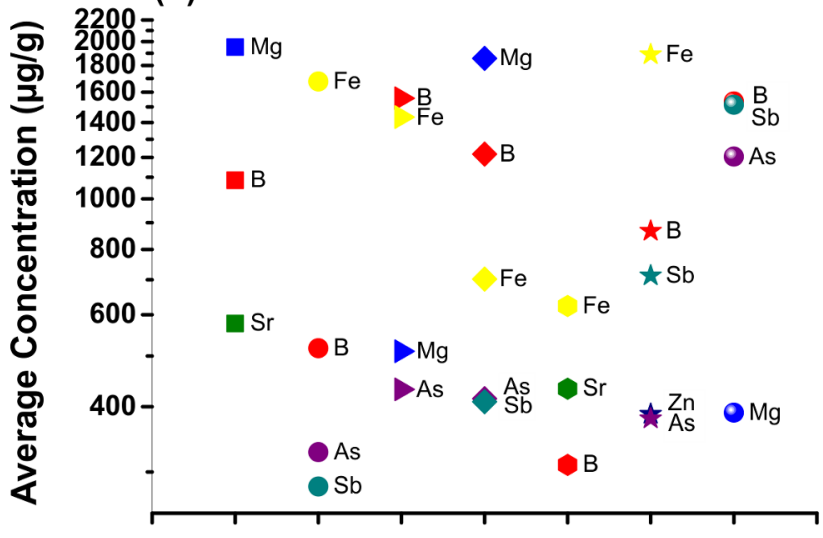

(c)

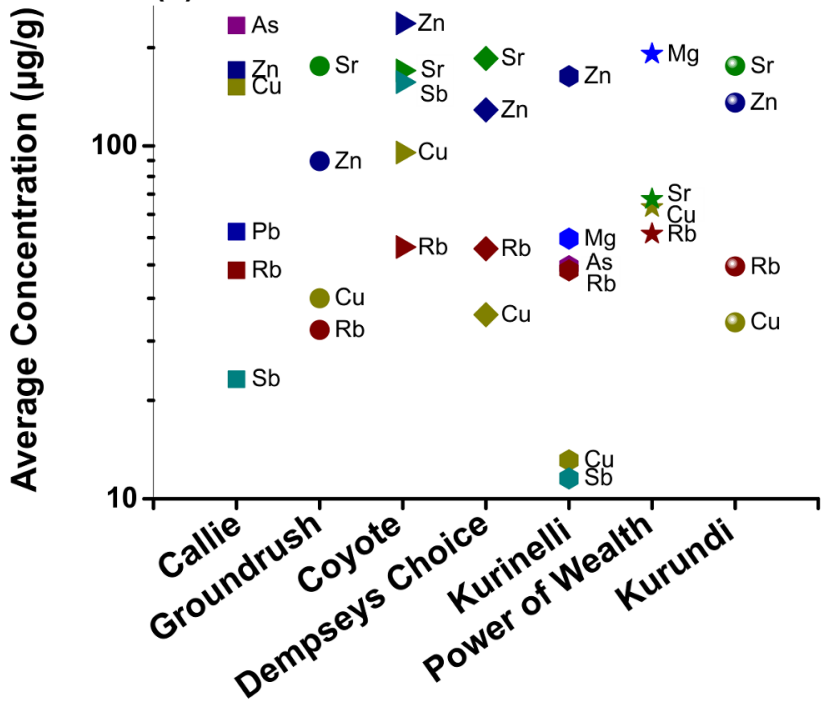

Fig. 8. Average element concentrations of LA-ICPMS data from all Fluid Inclusion Assemblages analysed in each ore deposit.

plot of Sr-As-Rb ratios for the Tamani goldfield (Fig. 9c) show a spread of values from B-rich, magmatic influenced fluid to the Sr-rich, sedimentary influenced fluid, with the Groundrush deposit having a higher sedimentary influence than the Coyote deposit. Arsenic concentrations in inclusions from the Callie deposit were below detection limits. The $\mathrm{Sr}-\mathrm{As}-\mathrm{Rb}$ ratios for the Kurundi - Kurinelli goldfields (Fig. 9d) lie in two distinct groups. The first group is As-rich and plot in the magmatic vapour field, whereas inclusions from the Kurinelli deposit are very Aspoor but extremely $\mathrm{Sr}$ enriched. The Sr-Cs-Rb ternary plot for the
Tanami goldfield (Fig. 9e) extends from the magmatic vapour field to beyond the sedimentary influenced field with some samples being extremely enriched in $\mathrm{Sr}$ compared to $\mathrm{Cs}$ and $\mathrm{Rb}$. The corresponding plot for the Kurundi - Kurinelli goldfields (Fig. 9f) shows a much wider spread of data with the fluids generally more enriched in Cs than for the Tanami goldfield. In all cases, the very high $\mathrm{Sr}$ content of the samples from the Kurinelli deposit indicates that the fluids in this deposit have experienced a strong sedimentary influence.

\section{Discussion}

\subsection{Comparisons with other gold deposits}

Large et al. (2016) have used data from a number of hydrothermal ore deposits to show that trace element ratios can be used to distinguish fluid end members. We have compared our data with their results in Fig. 9. Our results are similar to the study of the Carlin fluids (Large et al., 2016) and indicate a progression from B-As-enriched (magmatic) fluid to a highly Sr-Ba-enriched fluid as a result of interaction with sedimentary rocks. In the Tanami goldfield the Groundrush deposit appears to span across both regions which may be due to the multiple phases of fluid flow. The data from the Coyote deposit, on the other hand, is mostly confined to the magmatic field. In the Kurundi - Kurinelli goldfields the trace element data from the Dempseys Choice and Power of Wealth deposits lie mostly within the magmatic field while the Kurinelli deposit, with its very high Sr ratios, has a strong sedimentary influence.

Variations in the chemistry of the fluids at each deposit in this study (Fig. 8) may be due to either variations in the source fluids or fluid-rock interaction. The concentration of $\mathrm{Mg}$ appears to be sensitive to the presence of mafic rocks. The high $\mathrm{Mg}$ concentrations in fluids from the Groundrush deposit (2422 to $5227 \mu \mathrm{g} / \mathrm{g}$ ) are in accord with the $\delta^{18} \mathrm{O}$ data of the fluids ( 3.8 to $8.5 \%$ ) and Mg-rich biotite alteration in the Tanami region (Mernagh and Wygralak, 2007; Bagas et al., 2014) both of which suggest a magmatic or mixed magmatic/metamorphic source for the ore fluids (Mernagh and Wygralak, 2007). The Mg concentration in fluids from the Kurundi - Kurinelli goldfields are generally low with the exception of the Kurundi deposit which is hosted by basalt.

The concentrations of $\mathrm{Fe}, \mathrm{Zn}$ and $\mathrm{Cu}$ in all deposits analysed in this study are considerably higher than those reported for the Pampalo orogenic gold deposit (Fusswinkel et al., 2017) and generally higher than metamorphic vein systems (Rauchenstein-Martinek et al., 2014) but the average value for $\mathrm{Cu}(80 \pm 45 \mathrm{mg} / \mathrm{g})$ is similar to that reported by Garofalo et al. (2014). This is probably due to the higher salinity of the fluid inclusions from the gold deposits in this study as these metals are dominantly complexed with chloride ions (Wood and Samson, 1998). Fig. 10 shows a compilation of the chlorinity normalised molar concentrations of $\mathrm{Zn}$ and $\mathrm{Pb}$ (i.e., $\mathrm{m}_{\mathrm{Zn}} / \mathrm{m}_{\mathrm{Cl}}$ and $\mathrm{m}_{\mathrm{Pb}} / \mathrm{m}_{\mathrm{Cl}}$ ) for fluids from this study and also of magmatic-hydrothermal fluids and normal metamorphic fluids unrelated to orogenic gold deposits. It shows that the fluids in this study have $\mathrm{Zn}$ and $\mathrm{Pb}$ concentrations that lie towards the magmatic-hydrothermal end of the metamorphic - magmatic mixing trend. It is likely that the concentrations of $\mathrm{Pb}$ and $\mathrm{Zn}$ in the fluids was increased by the precipitation of sulfides such as pyrite, especially if the fluids initially have an excess of Fe over reduced $\mathrm{S}$. The precipitation of sulphides results in a sulfur-deficient fluid, which can retain high concentrations of $\mathrm{Pb}$ and $\mathrm{Zn}$ down to temperatures as low as $200^{\circ} \mathrm{C}$ (Heinrich et al., 2004). The concentration of $\mathrm{Pb}$ and $\mathrm{Zn}$ can be further enhanced by the increasing dissociation of the $\mathrm{HCl}^{\circ}$ species in response to cooling, which makes the fluid more acidic and capable of keeping $\mathrm{Pb}$ and $\mathrm{Zn}$ in solution (Tagirov et al., 1997).

In a study of OGDs from the Val-d'Or vein field in Canada, Beaudoin and Chiaradia (2016) reported Rb:Sr ratios $<0.035$ for vein tourmaline but reported that the $\mathrm{Rb}: \mathrm{Sr}$ ratios of the host rocks typically varied from 0.03 to 0.23 and concluded that the $\mathrm{Sr}$ (and $\mathrm{O}, \mathrm{H}$ ) isotope compositions of vein minerals indicate that the fluids were sourced from a crustal segment, similar to the local country rocks, and undergoing prograde metamorphism during burial in an accretionary setting. Although only a 

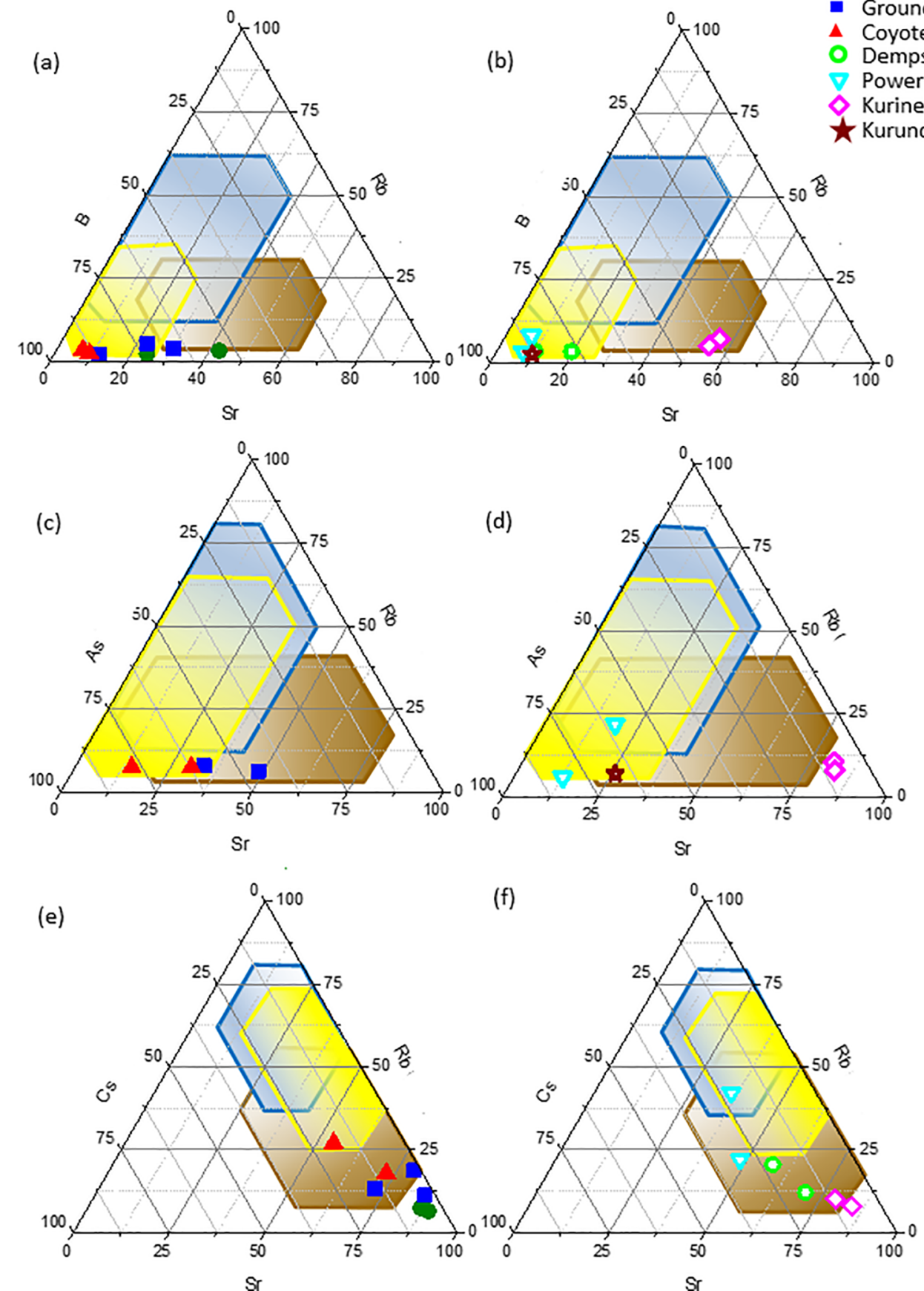

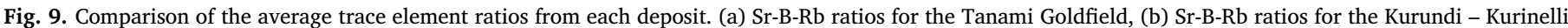

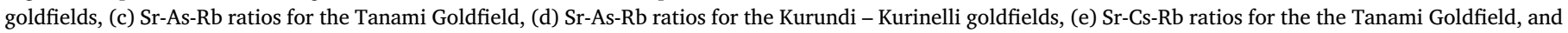

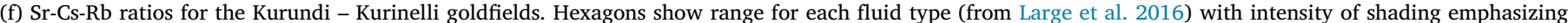

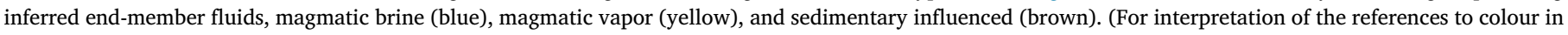
this figure legend, the reader is referred to the web version of this article.)

few data are available at present, the generally higher $\mathrm{Rb}: \mathrm{Sr}$ ratios obtained for deposits in this study indicate the involvement of magmatic fluids (Plimer and Elliott, 1979; Blevin and Chappell, 1995).

\subsection{Intrusion related gold deposits in the Tanami and Kurundi-Kurinelli goldfields}

Wall (2005) proposed that the gold mineralisation in the Tanami region was related to the thermal aureole around the granites. The author proposed that structurally-controlled plumbing systems channel the ore fluids into new or reactivated, pre-existing structures that formed at the time of granitoid emplacement. Tunks and Cooke (2007) carried out structural studies which indicated that gold veins in the Tanami district were part of an outer thermal aureole gold system that formed during the emplacement of the granitoids. Economic gold mineralisation was interpreted to occur late in the paragenetic history of the district. A summary of the geochronological data for the Tanami region is given in Table 3, which shows that the age of mineralisation is accepted as being approximately $1795 \mathrm{Ma}$ (Bagas et al., 2014). The occurrence of intrusion related gold deposits (e.g. the Buccaneer and Cypress deposits) in the 


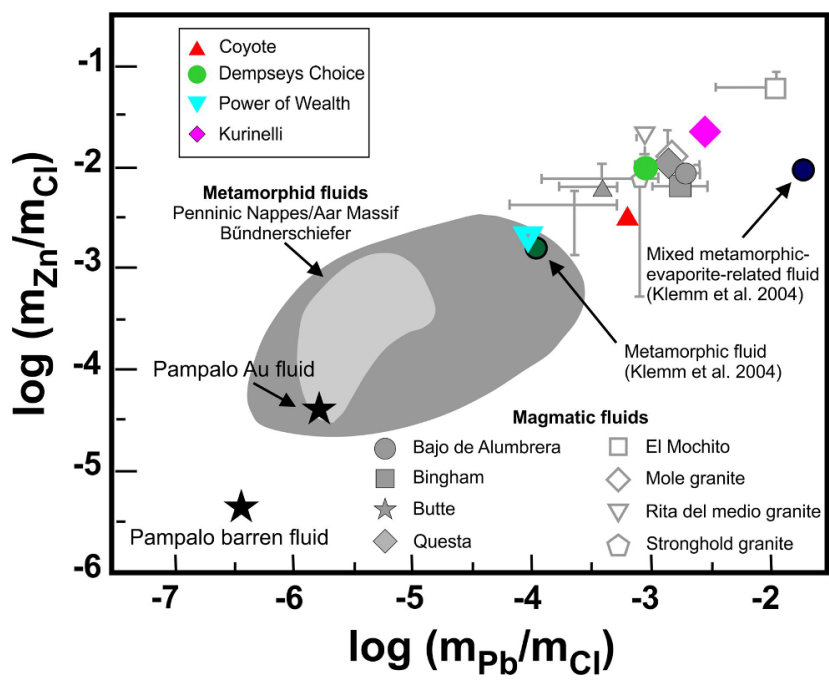

Fig. 10. A comparison of chlorine-normalised $\mathrm{Pb}$ and $\mathrm{Zn}$ concentrations for fluids from the Tanami and Kurundi - Kurinelli Goldfields with those of fluids from metamorphic and early magmatic-hydrothermal fluids. The data of metamorphic and magmatic-hydrothermal fluids are from Fusswinkel et al. (2017).

Tanami region (Bagas et al., 2014) provides further evidence for the involvement of magmatic fluids in the mineralisation process. Gold mineralisation at the Buccaneer deposit (Fig. 2) is hosted in the southern part of the ca 1795 Ma Twin Bonanza Porphyry (Smith, 2001), which also hosts the Cypress gold prospect in the north.

Large-scale mixing of metamorphic and magmatic-hydrothermal fluids released from granitic intrusions coeval with orogenic gold deposits has been previously proposed for many Archean and Phanerozoic orogenic gold provinces including the Tanami region (Walshe et al., 2003; Neumayr et al., 2008; Molnár et al., 2016; Wall, 2005; Tunks and Cooke, 2007). Lead isotope data from sulfides associated with mineralisation, K-feldspar, and whole rocks in the Tanami region (Huston et al., 2007) indicate a mixture of magmatic and crustal sources including the locally important ca 1795 Ma granites and metasedimentary host rocks. Arsenopyrite from Coyote's quartz veins has a $\delta^{34} S$ value of $1.5 \%$ relative to the $\mathrm{CDT}$ and can be also interpreted in terms of precipitation from a magmatic fluid, or sulfides derived from a magmatic source (Bagas et al., 2014). ${ }^{40} \mathrm{Ar} /{ }^{39} \mathrm{Ar}$ dating of sericite and ${ }^{207} \mathrm{~Pb} /{ }^{206} \mathrm{~Pb}$ dating of xenotime associated with gold mineralisation both indicate that mineralisation was coeval with magmatism during late-stage compression in the Tanami region (Table 3). Bagas et al. (2008) have also suggested that mafic rocks in the Tanami region were deposited in a backarc basin to island-arc setting, which is a favourable setting for IRGDs.
There have been fewer studies of the mineralisation in the KurundiKurinelli goldfields and these are much less detailed than in the Tanami region. The age of mineralisation is poorly constrained but is reported to be $1811 \mathrm{Ma}$ or younger (Donnellan, 2013). In many respects, this region has a similar lithologic, stratigraphic, igneous and metamorphic setting as in the Tanami Region. Ahmad et al. (2009) concluded that the gold-bearing, quartz vein deposits in the Kurundi - Kurinelli goldfields are most likely related to fractionated granitic intrusives at depth. This conclusion is supported by the $\mathrm{m}_{\mathrm{Zn}} / \mathrm{m}_{\mathrm{Cl}}$ and $\mathrm{m}_{\mathrm{Pb}} / \mathrm{m}_{\mathrm{Cl}}$ data shown in Fig. 10 although the data for the Power of Wealth deposit could indicate some mixing with metamorphic fluid.

Fluid inclusion studies in both the Tanami and Kurundi - Kurinelli goldfields (Mernagh and Wygralak, 2007; Wygralak and Mernagh, 2008) show that both regions possess coexisting $\mathrm{CO}_{2}$-rich fluid inclusions and two-phase aqueous inclusions. The latter inclusions exhibit a wide range of salinities, up to $22 \mathrm{wt} \% \mathrm{NaCl}$ eq. A comparison of the fluid inclusion data from the Tanami region with other major Australian gold deposits is shown in Fig. 11. These inclusions have much higher salinities than the fluids typically associated with OGDs formed from metamorphic fluids (generally $<13 \mathrm{wt} \% \mathrm{NaCl}$ equiv.; Ridley and Diamond, 2000; Fusswinkel et al., 2017). Therefore, the high salinity and trace element contents of fluids from the Tanami and Kurundi Kurinelli goldfields indicate that the gold deposits in both regions are most likely intrusion-related deposits.

The higher gold endowment of the Tanami deposits may be the result of multiple gold-mineralisation events in this region. Callie, the largest deposit in the Tanami region shows clear evidence of multiple mineralisation events (Bagas et al., 2014) and at least two episodes of hydrothermal alteration have been recognised at the Coyote deposit (Bagas et al., 2014). Furthermore, the geochronological data presented in Table 3 shows that a range of mineralisation ages have been obtained for some deposits (e.g. Coyote and Callie). While some of these ages are within error, they may also be the result of multiple mineralisation events. Although only one age is available for the Groundrush deposit, the CL image of the veining (Fig. 6) provides additional evidence of multiple fluid flow events. The fluid inclusion data from the Kurundi Kurinelli goldfields also indicate that there were at least two fluid flow events in this region (Wygralak and Mernagh, 2008) but the extent of fluid flow seems to be more limited as evidenced by the restricted extent of quartz veining $(\leq 200 \mathrm{~m})$. Therefore the lower endowment of the Kurundi - Kurinelli goldfields may be the result of a single mineralising event and/or the limited extent of fluid flow in this region.

\section{Conclusions}

This study has used cathodoluminescence (CL) and LA-ICPMS analyses of gold deposits in the Tanami and Kurundi-Kurinelli goldfields to

Table 3

Summary of geochronological data for the Tanami Region.

\begin{tabular}{|c|c|c|c|}
\hline Deposit & Age (Ma) & Method & Reference \\
\hline Coyote & 1738 & Lead Isotope Model Age & Huston et al. (2007) \\
\hline Coyote & 1628 & Lead Isotope Model Age & Huston et al. (2007) \\
\hline Coyote & $1791 \pm 8$ & SHRIMP xenotime ${ }^{207} \mathrm{~Pb} /{ }^{206} \mathrm{~Pb}$ & Bagas et al. (2007) \\
\hline Coyote & $1778 \pm 12$ & ${ }^{187} \mathrm{Re} /{ }^{188} \mathrm{Os}$ dating of sulphides & Bagas et al. (2014) \\
\hline Pebbles & 1749 & Lead Isotope Model Age & Huston et al. (2007) \\
\hline Callie & 1793 & Lead Isotope Model Age & Huston et al. (2007) \\
\hline Callie & $1803 \pm 19$ & SHRIMP xenotime ${ }^{207} \mathrm{~Pb} /{ }^{206} \mathrm{~Pb}$ & Cross et al. (2005) \\
\hline Carbine & 1047 & Lead Isotope Model Age & Huston et al. (2007) \\
\hline Groundrush & 1768 & Lead Isotope Model Age & Huston et al. (2007) \\
\hline Sandpiper & $1794 \pm 12$ & ${ }^{40} \mathrm{Ar} /{ }^{39} \mathrm{Ar}$ & Fraser et al. (2012) \\
\hline \multicolumn{4}{|l|}{ Granites } \\
\hline Birthday Suite & $1825-1815$ & SHRIMP zircon ${ }^{207} \mathrm{~Pb} /{ }^{206} \mathrm{~Pb}$ & Ahmad et al. (2013) \\
\hline Frederick Suite & $1815-1778$ & SHRIMP zircon ${ }^{207} \mathrm{~Pb} /{ }^{206} \mathrm{~Pb}$ & Ahmad et al. (2013) \\
\hline Grimwade Suite & $1821-1791$ & SHRIMP zircon ${ }^{207} \mathrm{~Pb} /{ }^{206} \mathrm{~Pb}$ & Ahmad et al. (2013) \\
\hline Twin Bonanza & $\sim 1795$ & SHRIMP zircon ${ }^{207} \mathrm{~Pb} /{ }^{206} \mathrm{~Pb}$ & Smith (2001) \\
\hline
\end{tabular}




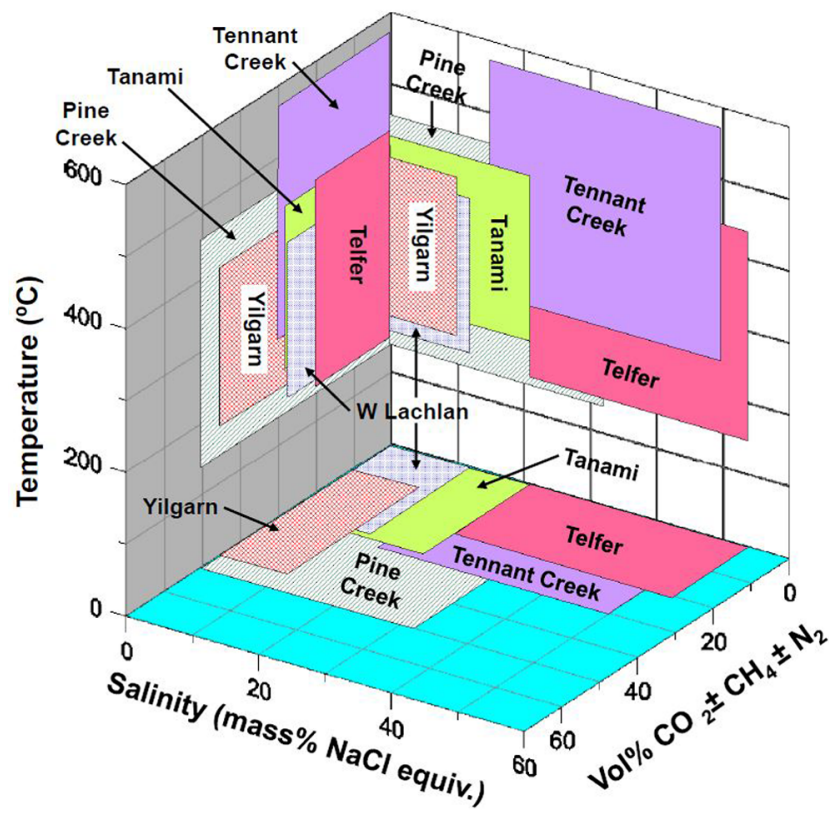

Fig. 11. A plot of temperature versus salinity versus vol. $\% \mathrm{CO}_{2} \pm \mathrm{CH}_{4} \pm \mathrm{N}_{2}$ for fluid inclusion data from the Tanami region and a number of other major Australian goldfields (modified from Mernagh et al., 2007).

investigate the source of the fluids and the factors that may affect the gold endowment in the two regions. CL imaging has shown the presence of up to three generations of chemically distinct quartz in fractured and mineralised veins from the Groundrush deposit, whereas only vein quartz of uniform CL composition was observed in the other deposits.

The LA-ICPMS data from fluid inclusions from all the deposits show elevated concentrations of $\mathrm{Na}, \mathrm{K}, \mathrm{As}, \mathrm{B}, \mathrm{Rb}, \mathrm{Sr}$ and $\mathrm{Sb}$ and indicate an evolution from B-As-enriched, magmatic fluid to a highly Sr-Ba-enriched fluid as a result of interaction with sedimentary rocks. Interaction with the sedimentary rocks appears to be more prevalent in the Kurundi Kurinelli goldfields than in the Tanami goldfield. $\mathrm{Rb}: \mathrm{Sr}$ ratios vary considerably but are generally higher than the ratios in orogenic gold deposits, and hence, indicate interaction with magmatic fluids.

The fluids from both regions in this study have chlorinity normalised $\mathrm{Zn}$ and $\mathrm{Pb}$ concentrations near the magmatic end of the metamorphic magmatic mixing trend for these elements. Previous dating of sericite and xenotime associated with mineralisation (Cross et al., 2005; Fraser et al., 2012; Bagas et al., 2014) both indicate that mineralisation in the Tanami region was coeval with magmatism. This is supported by the occurrence of intrusion-hosted gold deposits in this region. Therefore, the timing of the mineralisation, the relatively high salinity of the fluids in both the Tanami and Kurundi - Kurinelli goldfields, and their trace element contents all indicate that the deposits in both regions are intrusion-related gold deposits. The higher gold endowment of the Tanami region may result from the multiple gold-mineralisation events in this region whereas fluid flow associated with mineralisation in the Kurundi Kurinelli goldfields appears to be of limited extent.

\section{Declaration of Competing Interest}

The authors declare that they have no known competing financial interests or personal relationships that could have appeared to influence the work reported in this paper.

\section{Acknowledgements}

We thank Alexandre Tarantola, an anonymous reviewer and the Associate Editor, Olga Plotinskaya for their very helpful and constructive comments. This work was financially supported by Chinese Academy of
Sciences President's International Fellowship Initiative (Grant No. 2017VCB0018) to TPM, and by the National Natural Science Foundation of China (41773058), the Science and Technology Foundation of Guizhou Province ([2013]3083), the Opening Foundation of State Key Laboratory of Ore Deposit Geochemistry, and the Institute of Geochemistry, Chinese Academy of Sciences (201504).

\section{Appendix A. Supplementary data}

Supplementary data to this article can be found online at https:// doi.org/10.1016/j.oregeorev.2019.103189.

\section{References}

Ahmad, M., Wygralak, A.S., Ferenczi, P.A., 2009. Gold deposits of the Northern Territory, Second ed. Northern Territory Geological Survey, Darwin, Australia, pp. 131.

Ahmad, M., Vandenberg, L.C., Wygrala, K.A.S., 2013. Tanami Region. In: Ahmad, M., Munson, T.J. (Eds.), Geology and mineral resources of the Northern Territory. Northern Territory Geological Survey. Special Publication, Darwin, Australia, pp. $11-41$.

Allan, M.M., Yardley, B.W.D., Forbes, L.J., Shmulovich, K.I., Banks, D.A., Shepherd, T.J., 2005. Validation of LA-ICP-MS fluid inclusion analysis with synthetic fluid inclusions. Am. Mineral. 90, 1767-1775.

Audétat, A., Günther, D., Heinrich, C.A., 1998. Formation of a magmatic-hydrothermal ore deposit: insights with LA-ICP-MS analysis of fluid inclusions. Science 279, 2091-2094.

Audétat, A., Pettke, T., Heinrich, C.A., Bodnar, R.J., 2008. The composition of magmatic hydrothermal fluids in barren and mineralized intrusions. Econ. Geol. 103, 877-908.

Bagas, L., Anderson, J.A.C., Bierlein, F.P., 2009. Palaeoproterozoic evolution of the Killi Killi Formation and orogenic gold mineralization in the Granites-Tanami Orogen, Western Australia. Ore Geol. Rev. 35, 47-67.

Bagas, L., Bierlein, F.P., English, L., Andersonc, J.A.C., Maidmentd, D., Huston, D.L., 2008. An example of a Palaeoproterozoic back-arc basin: petrology and geochemistry of the ca. 1864Ma Stubbins Formation as an aid towards an improved understanding of the Granites-Tanami Orogen, Western Australia. Precambr. Res. 166, 168-184.

Bagas, L., Boucher, R., Li, B., Miller, J., Hill, P., Depauw, G., Pascoe, J., Eggers, B., 2014. Paleoproterozoic stratigraphy and gold mineralisation in the Granites-Tanami Orogen, North Australian Craton. Aust. J. Earth Sci. 61, 89-111. https://doi.org/10. 1080/08120099.2013.784220.

Bagas, L., Huston, D.L., Anderson, J., Mernagh, T.P., 2007. Paleoproterozoic gold deposits in the Bald Hill and Coyote areas, western Tanami, Western Australia. Miner. Deposita 42, 127-144. https://doi.org/10.1007/s00126-006-0092-4.

Baggott, M., Schmeider, S., Robinson, C., 2016. Exploration success and resource growth at Newmont's Tanami Operations, Northern Territory. AGES 2016. Northern Territory Geological Survey, Alice Springs, Australia, p. 15.

Baker, T., 2002. Emplacement depth and carbon dioxide-rich fluid inclusions in intrusionrelated gold deposits. Econ. Geol. 97, 1111-1117.

Baker, T., Lang, J.R., 2001. Fluid inclusion characteristics of intrusion-related gold mineralization, Tombstone-Tungsten magmatic belt, Yukon Territory, Canada. Min. Dep. 36, 563-582.

Beaudoin, G., Chiaradia, M., 2016. Fluid mixing in orogenic gold deposits: evidence from the H-O-Sr isotope composition of the Val-d'Or vein field (Abitibi, Canada). Chem. Geol. 437, 7-18.

Blevin, P.L., Chappell, B.W., 1995. Chemistry, origin, and evolution of mineralized granites in the lachlan fold belt, Australia: the metallogeny of I- and S-type granites. Econ. Geol. 90, 1604-1619.

Blevin, P.L., 2004. Redox and Compositional Parameters for Interpreting the Granitoid Metallogeny of Eastern Australia. Res. Geol. 54, 241-252.

Blevin, P.L., 2005. Intrusion Related Gold Deposits. ecat.ga.gov.au/geonetwork/srv/eng/ catalog.search;jsessionid = D03F483A27CD632ABB86B21454BAB237\#/metadata/ 63681 (Last Accessed 07/03/2019).

Cross, A.J., Fletcher, I.R., Crispe, A.J., Huston, D.L., Williams N., 2005. New constraints on the timing of deposition and mineralization in the Tanami Group. Annual Geoscience Exploration Seminar (AGES) 2005: Record of Abstracts, Northern Territory Geological Survey Record 2005-0001.

Donnellan, N., 2013. Warramunga Province, in: Ahmad, M., Munson, T.J. (eds), Geology and mineral resources of the Northern Territory. Northern Territory Geological Survey, Special Publication 5, Darwin, Australia, 9:1-9:61.

Fraser, G.L., Bagas, L., Huston, D.L., 2012. ${ }^{40} \mathrm{Ar} /{ }^{39} \mathrm{Ar}$ evidence for the timing of Paleoproterozoic gold mineralisation at the Sandpiper Deposit, Tanami region, northern Australia. Aust. J. Earth Sci. 59, 399-409.

Fusswinkel, T., Wagner, T., Sakellaris, G., 2017. Fluid evolution of the Neoarchean Pampalo orogenic gold deposit (E Finland): constraints from LA-ICPMS fluid inclusion microanalysis. Chem. Geol. 450, 96-121. https://doi.org/10.1016/j.chemgeo. 2016.12.022.

Garofalo, P.S., Fricker, M.B., Günther, D., Bersani, D., Paolo Lottici, P., 2014. Physicalchemical properties and metal budget of Au-transporting hydrothermal fluids in orogenic deposits. Geol. Soc London, Special Pub. 402, 71-102. https://doi.org/10. $1144 / \mathrm{sp} 402.8$.

Goldfarb, R.J., Baker, T., Dube, B., Groves, D.I., Hart, C.J.R., Gosselin, P., 2005. Distribution, character, and genesis of gold deposits in metamorphic terranes. Econ. 
Geol. 100th Anniversary Volume, pp. 407-450.

Goldfarb, R.J., Groves, D.I., 2015. Orogenic gold: common or evolving fluid and metal sources through time. Lithos 233, 2-26. https://doi.org/10.1016/j.lithos.2015.07. 011.

Goldstein, R.H., Reynolds, T.J., 1994. Systematics of Fluid Inclusions in Diagenetic Minerals. Society for Sedimentary Geology, Tulsa, Oklahoma.

Groves, D.I., Goldfarb, R.J., Robert, F., Hart, C.J.R., 2003. Gold deposits in metamorphic belts: overview of current understanding, outstanding problems, future research, and exploration significance. Econ. Geol. 90, 1-29.

Guillong, M., Latkoczy, C., Seo, J.H., Gunther, D., Heinrich, C.A., 2008. Determination of sulfur in fluid inclusons by laser ablation ICP-MS. J. Anal. Atomic Spec. 23, 1581-1589.

Harlaux, M., Mercadier, J., Bonzi, W.M.-E., Kremer, V., Marignac, C., Cuney, M., 2017. Geochemical signature of magmatic-hydrothermal fluids exsolved from the beauvoir rare-metal granite (Massif Central, France): insights from LA-ICPMS analysis of primary fluid inclusions. Geofluids 2017, 1-25. https://doi.org/10.1155/2017/ 1925817.

Hart, C.J.R., 2007. Reduced intrusion-related golds ystems. In: W.D.Goodfellow (Ed) Mineral deposits of Canada: A Synthesis of Major Deposit Types, District Metallogeny, the Evolution of Geological Provinces, and Exploration Methods, Geol. Assoc. Canada, Mineral Deposits Division, Special Pub. No.5, 95-112.

Hart, C.J.R., Goldfarb, R.J., 2005. Distinguishing intrusion-related from orogenic gold systems. In: Proceedings of the 2005 New Zealand Minerals Conference, Auckland, Nov. 13-16, p. 125-133.

Heinrich, C.A., Driesner, T., Stefansson, A., Seward, T.M., 2004. Magmatic vapor contraction and the transport of gold from the porphyry environment to epithermal ore deposits. Geology 32, 761-764.

Hoatson, D.M., Claoué-Long, J.C., Jaireth, S., 2007. A Synthesis of Australian Proterozoic Mafic-Ultramafic Magmatic Events: Part 2: Northern Territory and South Australia (1:4,000,000 scale map). Geoscience Australia, Canberra Australia.

Huston, D.L., Vandenberg, L., Wygralak, A.S., Mernagh, T.P., Bagas, L., Crispe, A., Lambeck, A., Cross, A., Fraser, G., Williams, N., Worden, K., Meixner, T., Goleby, B., Jones, L., Lyons, P., Maidment, D., 2007. Lode-gold mineralization in the Tanami region, northern Australia. Min. Dep. 42, 175-204.

Kerr, M.J., Hanley, J.J., Kontak, D.J., Gordon, G., Morrison, G.G., Petrus, J., Fayek, M., Zajacz, Z., 2018. Evidence of upgrading of gold tenor in an orogenic quartz-carbonate vein system by late magmatic-hydrothermal fluids at the Madrid Deposit, Hope Bay Greenstone Belt, Nunavut, Canada. Geochim. Cosmochim. Acta 241, 180-218.

Klemm, L., Pettke, T., Graeser, S., Mullis, J., Kouzmanov, K., 2004. Fluid mixing as the cause of sulphide precipitation at Albrunpass, Binn Valley, Central Alps, Swiss Bull. Min. Petrol. 84, 189-212.

Lan, T.G., Hu, R.Z., Fan, H.R., Bi, X.W., Tang, Y.W., Zhou, L., Mao, W., Chen, Y.H., 2017a. In-situ analysis of major and trace elements in fluid inclusion and quartz: LA-ICP-MS method and applications to ore deposits. Acta Petrol. Sin. 33, 3239-3262 (in Chinese with English abstracts).

Lan, T.G., Hu, R.Z., Bi, X.W., Mao, G.J., Wen, B.J., Liu, L., Chen, Y.H., 2017b. Metasomatized asthenospheric mantle contributing to the generation of $\mathrm{Cu}-\mathrm{Mo}$ deposits within an intracontinental setting: a case study of the $\sim 128$ Ma Wangjiazhuang Cu-Mo deposit, eastern North China Craton. J. Asian Earth Sci. 160, 460-489.

Lang, J.R., Baker, T., 2001. Intrusion-related gold systems: the present level of understanding. Min. Dep. 36, 477-489.

Large, S.J.E., Bakker, E.Y.N., Weis, P., Wälle, M., Ressel, M., Heinrich, C.A., 2016. Trace elements in fluid inclusions of sediment-hosted gold deposits indicate a magmatichydrothermal origin of the Carlin ore trend. Geology 44, 1015-1018. https://doi.org/ 10.1130/g38351.1.

Marsala, A., Wagner, T., Wälle, M., 2013. Late-metamorphic veins record deep ingression of meteoric water: a LA-ICPMS fluid inclusion study from the fold-and-thrust belt of the Rhenish Massif, Germany. Chem. Geol. 351, 134-153.

Marsh, E.E., Goldfarb, R.J., Hart, C.J., Johnson, C.A., 2003. Geology and geochemistry of the Clear Creek intrusion-related gold occurrences, Tintina Gold Province, Yukon, Canada. Can. J. Earth Sci. 40, 681-699.

Marsh, E.E., Allan, M., Goldfarb, R.J., Jensen, P., Mair, J.L., Shepherd, T.J., 2005. LA-ICPMS Microanalysis of single fluid inclusions from intrusion-related gold deposits, Tintina Gold Province, Alaska and Yukon. Geol. Soc. Am. Abstracts Progr. 37, 501.

McCuaig, T.C., Kerrich, R., 1998. P-T-t-deformation-fluid characteristics of lode gold deposits: evidence from alteration systematics. Ore Geol. Rev. 12, 381-453.

Mernagh, T.P., Bastrakov, E.N., Zaw, K., Wygralak, A.S., Wyborn, L.A.I., 2007. A comparison of fluid inclusion data and mineralization processes for Australian Orogenic Gold and Intrusion-Related Gold Systems. Acta Petrol. Sin. 23, 21-32.

Mernagh, T.P., Wygralak, A.S., 2007. Gold ore-forming fluids of the Tanami region,
Northern Australia. Min. Dep. 42, 145-173.

Molnár, F., Mänttäri, I., O'Brien, H., Lahaye, Y., Pakkanen, L., Johanson, B., Käpyaho, A., Sorjonen-Ward, P., Whitehouse, M., Sakellaris, G., 2016. Boron, sulphur and copper isotopes systematics in the orogenic gold deposits of the Archaean Hattu schist belt, eastern Finland. Ore Geol. Rev. 77, 133-162.

Neumayr, P., Walshe, J.L., Hagemann, S.G., Petersen, K., Roache, A., Frikken, P., Horn, L., Halley, S., 2008. Oxidized and reduced mineral assemblages in greenstone belt rocks of the St. Ives gold camp, Western Australia: vectors to high-grade ore bodies in Archaean gold deposits? Min. Dep. 43, 363-371.

Orville, P.M., 1963. Alkali ion exchange between vapor and feldspar phases. Am. J. Sci. 261, 201-237.

Pettke, T., Oberli, F., Audétat, A., Guillong, M., Simon, A.C., Hanley, J.J., Klemm, L.M., 2012. Recent developments in element concentration and isotope ratio analysis of individual fluid inclusions by laser ablation single and multiple collector ICP-MS. Ore Geol. Rev. 44, 10-38. https://doi.org/10.1016/j.oregeorev.2011.11.001.

Phillips, G.N., 1993. Metamorphic fluids and gold. Miner. Mag. 57, 365-374.

Phillips, G.N., Powell, R., 2010. Formation of gold deposits-a metamorphic devolatilization model. J. Metamorp. Geol. 28, 689-718.

Plimer, I.R., Elliott, S.M., 1979. The use of Rb/Sr ratios as a guide to mineralization. J. Geochem. Explor. 12, 21-34.

Rauchenstein-Martinek, K., Wagner, T., Wälle, M., Heinrich, C.A., 2014. Gold concentrations in metamorphic fluids: a LA-ICPMS study of fluid inclusions from the Alpine orogenic belt. Chem. Geol. 385, 70-83. https://doi.org/10.1016/j.chemgeo. 2014.07.018.

Ridley, J.R., 2006. Differentiating Crustal Fluids in the Eastern Tintina Gold Province of Alaska and Yukon: Implications for the Genesis and Distribution of Gold Ores, U.S. Geol. Surv. Mineral Resources External Research Program - Final Reports. p. 25. https://minerals.usgs.gov/mrerp/reports.html\#2006.

Ridley, J.R., Diamond, L.W., 2000. Fluid chemistry of orogenic lode gold deposits and implications for genetic models. In: Hagemann, S.G., Brown, P.E. (Eds), Gold in 2000, Rev. Econ. Geol. 13. pp. 141-162.

Rusk, B.G., 2012. Cathodoluminescence and trace elements in hydrothermal quartz. In: Götze, J., Möckel, R. (Eds.), Quartz: Deposits, Mineralogy and Analytics. Springer, Berlin, pp. 307-329.

Rusk, B.G., Reed, M.H., Dilles, J.H., 2004. Compositions of magmatic hydrothermal fluids determined by LA-ICP-MS of fluid inclusions from the porphyry copper-molybdenum deposit at Butte, MT. Chem. Geol. 210, 173-199.

Seo, J.H., Guillong, M., Heinrich, C.A., 2012. Separation of molybdenum and copper in porphyry deposits: the roles of sulfur, redox, and $\mathrm{pH}$ in ore mineral deposition at Bingham Canyon. Econ. Geol. 107, 333-356.

Smith, J.B., 2001. Summary of results-Joint NTGS-AGSO Age Determination Program 1999-2001. Northern Territory Geol. Surv. Record 2001-2007.

Tagirov, B.R., Zotov, A.V., Akinfiev, N.N., 1997. Experimental study of dissociation of HCl from 350 to $500{ }^{\circ} \mathrm{C}$ and from 500 to 2500 bars: thermodynamic properties of $\mathrm{HCl}^{\circ}$ (aq). Geochim. Cosmochim. Acta 61, 4267-4280.

Thompson, J.F.H., Newberry, R.J., 2000. Gold deposits related to reduced granitic intrusions. In: Hagemann, S.G., Brown, P.E. (eds), Gold in 2000, Rev. Econ. Geol. 13, 377-400.

Tunks, A.J., Cooke, D.R., 2007. Geological and structural controls on gold mineralization in the Tanami District, Northern Territory. Min. Dep. 42, 107-126.

Ulrich, T., Günther, D., Heinrich, C.A., 1999. Gold concentrations of magmatic brines and the metal budget of porphyry copper deposits. Nature 399, 676-679.

Ulrich, T., Günther, D., Heinrich, C.A., 2002. The evolution of a porphyry Cu-Au deposit, based on LA-ICP-MS analysis of fluid inclusions: Bajo de la Alumbrera, Argentina. Econ. Geol. 97, 1889-1920.

Wall, V.J., 2005. TAG: Thermal aureole (pluton-related) gold systems, AIG News, Australian Institute of Geoscientists, 1-7.

Walshe, J., Halley, S., Hall, G., Kitto, P., 2003. Contrasting fluid systems, chemical gradients and controls on large-tonnage, high-grade Au deposits, Eastern Goldfields Province, Yilgarn Craton, Western Australia, Biennial SGA Meeting. Athens, Greece, pp. $827-830$.

Wood, S.A., Samson, I.M., 1998. Solubility of ore minerals and complexation of ore metals in hydrothermal solutions. Rev. Econ. Geol. 10, 33-80.

Wygralak, A.S., Mernagh, T.P., 2008. Composition, provenance and timing of hydrothermal fluids in the Tanami - Arunta Regions. Northern Territory Geological Survey, Technical Report GS2008-004. Northern Territory Geol. Surv., Darwin, Australia.

Zhou, L., Mavrogenes, J., Spandler, C., Li, H., 2016. A synthetic fluid inclusion study of the solubility of monazite-(La) and xenotime-(Y) in $\mathrm{H}_{2} \mathrm{O}-\mathrm{Na}-\mathrm{K}-\mathrm{Cl}-\mathrm{F}-\mathrm{CO}_{2}$ fluids at 800 ${ }^{\circ} \mathrm{C}$ and $0.5 \mathrm{GPa}$. Chem. Geol. 442, 121-129. 